\title{
CZYSTO LUDZKA SPRAWA? \\ ARCHEOLOGICZNE PRZYWRACANIE PAMIECCI \\ O TRUDNEJ PRZESZLOŚCI PRZEZ TROPIENIE NATURO-KULTUROWYCH PRZEMIAN CMENTARZY WOJENNYCH
}

\author{
SIMPLY HUMAN CASE? \\ ARCHAEOLOGICAL REVIVAL OF THE MEMORY ABOUT \\ THE DIFFICULT PAST, THROUGH THE TRACING \\ OF NATURE-CULTURAL TRANSFORMATIONS \\ OF THE WAR CEMETERIES
}

\author{
Anna Zalewska \\ Instytut Archeologii, Uniwersytet Marii Curie Skłodowskiej \\ Plac Marii Curie Słodowskiej 4, Lublin \\ azalew@op.pl \\ Dorota Cyngot \\ Instytut Archeologii i Etnologii Polskiej Akademii Nauk \\ Jacek Czarnecki \\ Eurozet, Collegium Civitas \\ Grzegorz Kiarszys \\ Instytut Historii i Stosunków Międzynarodowych, Uniwersytet Szczeciński
}

\begin{abstract}
In this article the outcomes of historical, archaeological, spatial and anthropological research concerning material remnants of the war cemeteries left by the Great War in Central Poland, in the area of Rawka and Bzura are presented. On the example of one of the four communes (Nowa Sucha) subjected to research under the project Archaeological Revival of Memory of the Great War (ARM), the processes of creation, transformation, decay, destruction and re-making present the resting places of the
\end{abstract}


soldiers fallen between December 1914 and July 1915 are shown. In the first part, we sketch the output atmosphere that accompanied the primary context in which war cemeteries were established and place the war cemeteries in the network of social, formal and legal determinants. In the second part, we frame the historical and social contexts in which the resting places of the fallen soldiers of the German and Russian armies were massively created. Than, we show the difficulties associated with locating particular war cemeteries and signal strengths and obstacles in correlating results of archival research and use of remote sensing and archaeological methods in order to restore the memory of war cemeteries and establish their current and future condition as material warnings. Also we stress the looping of cultural and natural factors both in the process of protecting and destroying material condition of war cemeteries. Finally, on the example of one of the cemeteries we show how slow and arduous but at the same time promising can be the process of transformation from a forgotten/plowed cemetery into a place of/in memory, and as an agent struggling with the continuous nature-cultural transformations.

KEY WORDS: war cemeteries, the Great War, central Poland, creation, transformation, decay, destruction, history, archaeology, remote sensing, natural-cultural phenomena and processes, difficult past, material warnings, contemporaneous archaeology

\section{PODLEGAJĄCE CIĄGLEJ PRZEMIANIE CMENTARZE WOJENNE NA TERENIE GMINY NOWA SUCHA (WOJEWÓDZTWO MAZOWIECKIE)}

„Rano, od strony Sochaczewa słychać było wystrzały. Na ulicach (Warszawy, przyp. A.Z.) spotkać można było transporty $\mathrm{z}$ rannymi. Wydaje się, że znajdujemy się niedaleko od czołowych pozycji. Może i zdarzy się coś takiego, że Niemcy nas nakryją i wszyscy będą kryć się jak przestraszona zwierzyna" - zapisał w swoim wojennym pamiętniku pod datą 6 декабря (czyli 19 grudnia) będący w drodze na front Andriej Kuzniecow, szeregowy żołnierz 49. Pułku Strzelców Syberyjskich 2. Armii Imperium Rosyjskiego (Kuzniecow, 1915).

Nie mylił się. Już wkrótce na odcinku walk, które utknęły między Sochaczewem a Skierniewicami, strach zaczął narastać i dominować nad innymi emocjami, zwłaszcza w kontekście masowej śmierci towarzyszy broni po obydwu stronach linii frontu, której apogeum przypadło na tym odcinku na koniec stycznia i początek lutego $1915 \mathrm{r}$. Apogeum to pozostawiło po sobie kilkaset cmentarzy i mogił wojennych. To wówczas do warszawskich, łowickich, sochaczewskich, skierniewickich, szymanowskich, guzowskich, włocławskich itd. szpitali i lazaretów przywożono tysiące rannych, którym starano się pomóc. Równie masowo tworzono przy nich cmentarze wojenne.

Dokładnie w tym samym czasie łowicki regionalista, społecznik i autor prac historycznych Władysław Tarczyński zanotował w swej pisanej od pierwszych dni wojny Kronice dziejów Łowicza informację, która z perspektywy zaplecza frontu oddawała w skrócie wydarzenia dni od 19 do 24 grudnia 1914 r. Próbował przy tym lokalizować omawiane wypadki: „Wojska rosyjskie, po opuszczeniu dnia $17 \mathrm{bm}$. miasta, zatrzymały się za Łowiczem, za rzeką Bzurą i Rawką, na linii Brochów - 
Sochaczew - Kozłów Biskupi - Bolimów itd., w lesie pod Skierniewicami. Wszędzie w odległości 15-18-24 wiorst" (Tarczyński, 2015, s. 180).

$\mathrm{Z}$ kolei biorący udział w tych walkach po stronie niemieckiej porucznik rezerwy 49. Pułku Piechoty 9. Armii Cesarstwa Niemieckiego R. Eisermann tak ujął wydarzenia z zimy 1914/1915 w swoim dzienniku wojennym, z którego również wyziera strach i odruch niezgody, obok wysoce zideologizowanej postawy:

Nasi dzielni ludzie leżeli setkami przed i za naszymi liniami, martwi i ranni [...] Święta niedolo - Święta niedolo - Nasza młodzież całuje śmierć. [...] W naszym wysuniętym najbardziej do przodu okopie zgromadzili się wszyscy. Gdyby teraz wstrzeliła się tutaj rosyjska artyleria, to doszłoby do okropnego mordowania! [...] Dlaczego tylko to bezsensowne mordowanie, myślałem sobie wówczas! (za: Rothe, 1929, s. 44)

Wyrażony w tych słowach odruch współczucia i trwogę porucznik z czasem racjonalizował w następujący sposób:

Dopiero o wiele później zrozumiałem sens tego ważnego zadania. W tych samych dniach na Mazurach Hindenburg prowadził swoje wojsko przez śnieg i lód do bitwy zimowej nad Jeziorami Mazurskimi, a w Karpatach rozpoczynały się kontruderzenia Niemców oraz Austriaków i Węgrów w celu wyparcia Rosjan z tych ziem. Armii Rosyjskiej, która do tej pory stała naprzeciwko nas nad Rawką i osłaniała twierdzę Warszawa, miano uniemożliwić przerzucenie wojska na północ i południe. Dlatego więc „Wrogowi należało pokazać wojsko", dlatego więc musieliśmy zaoferować wrogowi nasze ciała w całej ich wielkości, jako kulochwyt; jednak dlatego również my, walczący nad Rawką, mogliśmy zapisać sobie na nasze konto w naszym pisanym krwią dzienniku wojennym część sukcesu na Mazurach oraz w Karpatach. (za: Rothe, 1929, s. 45)

Ten ,pisany krwią dziennik wojenny” znalazł swój ponadczasowy epilog w postaci cmentarzy wojennych, których dziesiątki powstały na objętym Wielką Wojną odcinku frontu między Sochaczewem a Skierniewicami (szerzej na temat kontekstu historycznego walk na terenie gminy Nowa Sucha por.: Rozdżestwieński, Wojewoda, 2013; Kaliński, 2015; Zalewska, Czarnecki, 2016; o cmentarzach powstałych po walkach nad Rawką i Bzurą w gminach Bolimów i Wiskitki por. też: Zalewska, 2016b; Zalewska, Kiarszys 2017; Zalewska, Cyngot, 2017 〈gm. Bolimów〉; Zalewska, Cyngot, Czarnecki, Kiarszys, 2018 (gm. Wiskitki〉).

Obecność cmentarzy wojennych w rejonie Rawki i Bzury była problematyczna i dyskusyjna już na etapie procesu depozycyjnego. Etap ten przypadał na okres, gdy na terenie centralnej Polski toczyły się krwawe bitwy na linii frontu, na której ustabilizował się front walk pozycyjnych między armiami Imperium Rosyjskiego i Cesarstwa Niemieckiego, oraz na okres międzywojnia, gdy część cmentarzy była komasowana i/ lub niszczona.

W niniejszym artykule prezentujemy wyniki wglądu w proces tworzenia, przekształcania, zaniku (przez naturalny rozkład, ale i niszczenie) i ponownego uobec- 
niania cmentarzy i mogił wojennych żołnierzy poległych w latach 1914-1915 w rejonie Rawki i Bzury w centralnej Polsce. Na tym konkretnym przykładzie staramy się jednak ukazać bardziej uniwersalne zjawiska i procesy, które następują pod wpływem złożonych i zapętlonych czynników naturo-kulturowych w wielu miejscach na świecie. Na przykładzie wybranego obszaru, arbitralnie ograniczonego do administracyjnych granic gminy Nowa Sucha, ukazujemy, że nieustannie, w tym również na naszych oczach i w naszym otoczeniu - i nie tylko w odniesieniu do cmentarzy i mogił wojennych z czasu pierwszej wojny światowej - dokonuje się ciągła naturo-kulturowa transformacja pozostałości trudnej przeszłości, z którą warto (z pobudek ogólnoludzkich i ponadczasowych) się konfrontować.

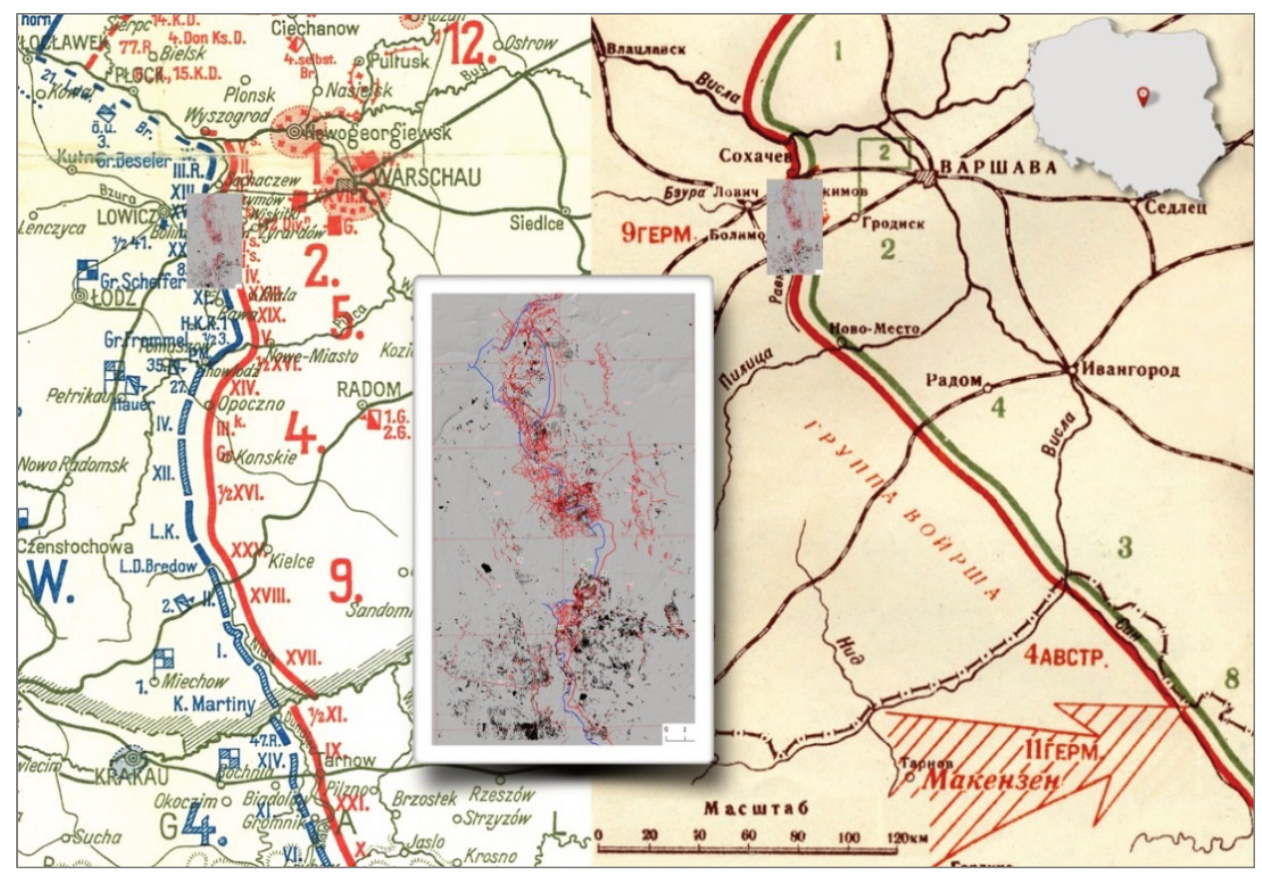

Ryc. 1. Obszar badań projektu pt. „Archeologiczne Przywracanie Pamięci o Wielkiej Wojnie. Materialne pozostałości życia i śmierci w okopach na froncie wschodnim oraz stan przemian krajobrazu pobitewnego w rejonie Rawki i Bzury" (APP), zobrazowany numerycznym modelem terenu, na którym oznaczono zadokumentowane $\mathrm{z}$ użyciem metod teledetekcyjnych materialne ślady działań wojennych 1914-1915 oraz schematycznie zaznaczono linię frontu (kolorem niebieskim i czerwonym). Tło stanowią mapy archiwalne obrazujące przebieg frontu w 1915 r. (Dane z bazy danych projektu APP, opracowanie graficzne A. I. Zalewska).

Fig. 1. The area of research of the project "Archaeological Revival of Memory of the Great War. Material remains of the life and death in trenches of the Eastern Front and the condition of the ever changing battlescape in the region of the Rawka and Bzura" (ARM), depicted by a numerical terrain model, on which were marked documented using remote sensing methods material traces of war opperations 1914-1915 and the schematic frontline (blue and red). As the background the archival maps showing the course of the front in 1915 were used (ARM's Data Base, designed by A. I. Zalewska). 
W wielu wypadkach zanik cmentarzy jest procesem naturalnym i akceptowalnym. Wyjątkiem są w naszej opinii te sytuacje, w których mogiły i cmentarze (tu: wojenne) podlegają intencjonalnemu niszczeniu z przyczyn ideowych, politycznych czy pragmatycznych, mimo że - jako niosące wartość społeczną, historyczną, poznawczą i symboliczną - teoretycznie zostały „desygnowane” przez człowieka do trwania w czasie jako „prawnie/teoretycznie” podlegające trwałej (!) ochronie. $\mathrm{Z}$ wszelkimi cmentarzami wojennymi łączy się $\mathrm{w}$ naszej opinii rola materialnych przestróg i kluczowych składowych „krajobrazów pamięci” o minionych wojnach. Na przykładzie wyników projektu „Archeologiczne Przywracanie Pamięci o Wielkiej Wojnie. Materialne pozostałości życia i śmierci w okopach na froncie wschodnim oraz stan przemian krajobrazu pobitewnego w rejonie Rawki i Bzury" (dalej APP, patrz: obszar objęty badaniami, ryc. 1) ukazujemy, jak takie założenie może się przełożyć na prospołeczną praktykę badawczą.

Artykuł rozpoczęliśmy od naszkicowania atmosfery emocjonalnej towarzyszącej kontekstowi pierwotnemu, w którym powstawały cmentarze wojenne $\mathrm{w}$ rejonie Rawki i Bzury w latach 1914-1915. Odwołujemy się do refleksji trzech świadków wydarzeń, aby ukazać w pełni transnarodowy, inicjacyjny moment nastania dominacji wojny, a tym samym lęku, trwogi i śmierci, która zaczęła panować nad człowiekiem i krajobrazem.

Poniżej wskazujemy współczesne definicje cmentarzy i grobów wojennych oraz konfrontujemy je z fragmentami wspomnień, zapisków i dokumentów archiwalnych z okresu wojny, aby ujawnić pojawiające się już we wczesnej fazie Wielkiej Wojny konfrontacje między żywymi i martwymi, których dalekosiężne konsekwencje obserwujemy po stu latach. W drugiej części opowiadamy o historycznym kontekście, w którym miejsca spoczynku poległych żołnierzy armii niemieckiej i rosyjskiej były ustanawiane na masową skalę, aby pokazać w dalszej części artykułu, jak materialna istota/kondycja cmentarzy wojennych jest uwikłana w naturo-kulturowy proces ich transformacji.

Czyniąc problem zanikających cmentarzy wojennych z okresu pierwszej wojny światowej przedmiotem refleksji ontologicznej, próbujemy również tym razem wyjść poza dyskurs archeologiczny skoncentrowany na epistemologii, podkreślając pozaepistemologiczne racje i wartości archeologii (por. argumenty stojące u podstaw takiego ukierunkowania m.in. w: Zalewska, 2012, 2013, 2014). Między innymi dlatego $\mathrm{w}$ toku procesu odkrywczego z jednej strony staraliśmy się dowieść, przez aktywne działania prospołeczne (jak m.in. wykłady, pogadanki, wystawy zabytków archeologicznych, publikacje skierowane do lokalnej społeczności, tablice informacyjne, uczestniczenie w lokalnych inicjatywach rekonstruowania cmentarzy wojennych i w ustanawianiu funkcjonujących dziś miejsc chowania szczątków żołnierzy Wielkiej Wojny), że archeologia rzeczywiście jest formą partycypacji w kulturze, która powinna być pełniej eksponowana i doceniana - choćby jako bodźcująca wrażliwość i świadomość historyczną lub jako stymulator refleksji nad przemijaniem, kwestią pośmiertnej godności człowieka czy ścisłych zależności między prze- 
szłością i teraźniejszością. APP, podobnie jak wiele aktywności z domeny archeologii czasów współczesnych (por. Zalewska, 2003, 2014, 2016a), szczególnie skutecznie wymyka się cuglom doxa, co jednak wymaga wytężonych działań (jak wszelkie formy nieklasycznej humanistyki, por. np. Domańska, 2006a, 2006b; Minta-Tworzowska, 2012; Kobiałka, Kostyrko, Kajda, 2017).

$\mathrm{Z}$ drugiej zaś strony problematyzujemy tytułowy znak zapytania przy stwierdzeniu, że cmentarze to „czysto ludzka sprawa” (?), nawiązując w toku reinterpretacji aktualnej kondycji materialnej cmentarzy wojennych do tezy o tętniącej życiem materii (vibrant matter), która uwrażliwia nas na istotę, sprawczość i rolę czynników nie w pełni zależnych od człowieka. Do koncepcji nowego (witalistycznego) materializmu (new materialism) (inspirowanego następującymi lekturami: Bennett, 2010; Domańska, 2017) ustosunkowujemy się tu pośrednio przez ukazanie, w jaki sposób masowa żołnierska śmierć była konfrontowana z życiem, jak roślinność porastająca cmentarze stała się ich strażnikiem oraz jak elementy architektury cmentarnej (w tym płyty nagrobne czy relikty pomnika) przyczyniły się do wychynięcia z (nie)bytu społecznego, na przykładzie jednego z cmentarzy wojennych (w Kozłowie Biskupim, stan. APP-27).

W przedostatniej części ukazujemy trudności związane z lokalizacją poszczególnych cmentarzy wojennych oraz sygnalizujemy przeszkody, z jakimi konfrontowane są wyniki badań archiwalnych oraz metod archeologicznych i teledetekcyjnych na drodze do przywracania pamięci o cmentarzach wojennych oraz wpływ tych czynników na ich aktualną i przyszłą kondycję. Wreszcie na przykładzie jednego z cmentarzy, którego stan rozpoznania uległ przemianie, dzięki czemu mógłby zmienić się jego status formalny i społeczny, pokazujemy, jak powolny i mozolny, ale również obiecujący jest proces przemiany materialnej obiektu/wycinka przestrzeni, np. z zapomnianego/zaoranego cmentarza w miejsce (w) pamięci.

$$
* * *
$$

Cmentarzami wojennymi w rozumieniu ustawy o grobach i cmentarzach wojennych są „,mentarze przeznaczone do chowania zwłok osób poległych w walkach o niepodległość i zjednoczenie państwa polskiego; wojskowych, poległych lub zmarłych z powodu działań wojennych, bez względu na narodowość; także sióstr miłosierdzia oraz jeńców wojennych i osób internowanych" (za: Ustawa z dnia 28 marca 1933 r. o grobach i cmentarzach wojennych Nr 39, poz. 311, art. 1.3 i 1.1, p. 1-4, dalej: Ustawa 1933).

Groby i cmentarze wojenne pozostają (bezczasowo, przyp. A.Z.) pod opieką Państwa. Zwierzchni nadzór nad nimi, polegający na sprawdzaniu i kontrolowaniu działań podległych jednostek pod względem legalności i podejmowania w tym zakresie decyzji administracyjnych, sprawuje minister właściwy do spraw kultury i ochrony dziedzictwa narodowego, z zachowaniem uprawnień przysługujących Kościołom i innym związkom wyznaniowym oraz wójtom (burmistrzom, prezydentom miast). (Ustawa 1933, art. 6.1) 
W świetle tej ustawy: „koszty budowy i utrzymywania, w tym remontów, grobów i cmentarzy wojennych, są ponoszone ze środków budżetu państwa" (Ustawa 1933, art. 6.2). Wojewoda, w drodze porozumienia, jest odpowiedzialny za powierzanie jednostce samorządu terytorialnego obowiązku ,utrzymania grobów i cmentarzy wojennych, z jednoczesnym przekazaniem odpowiednich funduszy, jeżeli jednostka samorządu terytorialnego nie przejmie tego obowiązku bezpłatnie" (Ustawa 1933, art. 6.3). Jednocześnie obowiązek utrzymania grobów i cmentarzy wojennych może być powierzony fundacjom, stowarzyszeniom i instytucjom społecznym, za ich zgodą, przez ministra właściwego do spraw kultury i ochrony dziedzictwa narodowego (Ustawa 1933, art. 6.4).

Teoretycznie powyższe formalno-prawne dyrektywy są oczywiście wystarczającą podstawą dla działań na rzecz otoczenia troską grobów i cmentarzy wojennych, w tym dokładnego określenia ich lokalizacji oraz dokumentowania stanu i wszelkich zmian, którym te obiekty podlegają. W praktyce jednak w okresie ostatnich 100 lat przepisy wynikające $\mathrm{z}$ ustawy okazały się niewystarczająco sugestywne/sprawcze, aby można było stwierdzić, że na terenie naszego kraju prawo to jest faktycznie realizowane.

Wnioski oparte na analizie i korelacji danych archiwalnych, teledetekcyjnych, geoprzestrzennych oraz wyników badań archeologicznych i historycznych zebranych w ramach archeologicznego przywracania pamięci o Wielkiej Wojnie, dające fragmentaryczny wgląd $\mathrm{w}$ materialny wymiar problemu grobownictwa pierwszowojennego, wykraczają poza sferę czysto poznawczą (epistemologiczną) (teza ta została rozwinięta $w$ innych miejscach, patrz: Zalewska, 2013, 2014, 2017). Zakładamy, że proces lokalizowania tych cmentarzy i upowszechniania wiedzy na temat kontekstu ich powstania i zanikania może się przyczynić do przywrócenia pamięci o wydarzeniach wojennych, o zmaganiach lokalnej ludności z pozostałościami wojny oraz o miejscach spoczynku żołnierzy (zagadnienie to zostało rozwinięte w innym miejscu, por. Zalewska, Cyngot, 2017, s. 141-142).

Za kluczową dla naszej powinności troski o miejsca spoczynku poległych żołnierzy oraz zasadności działań poznawczych i prospołecznych w odniesieniu do nieodległej przeszłości z czynnym udziałem archeologów obraliśmy przesłanie celnie wyartykułowane w piśmie, które wiosną 1922 r. trafiło do wójtów gmin polskich. Zostało ono wystosowane przez niemiecką organizację Volksbund Deutsche Kriegsgräber-Fürsorge e.V., skupiającą rodziny poległych żołnierzy i opiekującą się ich grobami, i określało konieczność troski o cmentarze wojenne jako niemającą „nic wspólnego z politycznemi ani gospodarczemi celami”. Ideę dbania o groby

\footnotetext{
${ }^{1}$ Zapis jak w oryginale. Również ponad dekadę później problem niszczenia cmentarzy wojennych z okresu Wielkiej Wojny wydawał się nieustannie palący. Na przykład w piśmie wystosowanym przez dyrektora Zentralnachweisamts für Kriegerverluste und Kriegergräber zawarto informację, że niemieccy obywatele, krewni żołnierzy pochowanych na terenie Polski skarżą się z powodu niemożności odnalezienia mogiły poległych, mimo że dysponują precyzyjnymi informacjami, gdzie dany poległy żołnierz
} 
określono w nim jako „czysto ludzką sprawę” (Akta Gminy Bolimów, zob. AGBol 58, k. 7, 7v).

Podane niżej argumenty unaoczniają, że „czysto ludzka sprawa”, jaką, wydawałoby się, powinna być troska o mogiły i cmentarze wojenne po Wielkiej Wojnie na terenie Polski, a więc także na terenie gminy Nowa Sucha, była i wciąż pozostaje niezwykle skomplikowana i daleka od zadowalającego, zgodnego z przepisami i z odczuciami zainteresowanych nią ludzi rozwiązania.

\section{WYDARZENIA HISTORYCZNE, KTÓRYCH SKUTEK STANOWIĄ (NIE)OBECNE CMENTARZE WOJENNE NA GRANICY WOJEWÓDZTW MAZOWIECKIEGO I ŁÓDZKIEGO}

W czasie I wojny światowej m.in. na terenie dzisiejszej gminy Nowa Sucha, gdzie przebiegał odcinek frontu wschodniego, armia rosyjska twardo broniła swoich pozycji, przez które wojska niemieckie próbowały przebić się w kierunku Warszawy. Armia rosyjska obsadziła linię obrony biegnącą od ujścia rzeki Sucha do Bzury przez Borzymówkę, Humin, Wolę Szydłowiecką po folwark Mogiły w grudniu 1914 r. Do początku stycznia 1915 r. na północnym krańcu tej linii, w rejonie Nowej Suchej, strona niemiecka zdołała zdobyć folwark Zakrzew, ale nie przejęła innych pozycji rosyjskich i sytuacja na tym odcinku frontu ustabilizowała się na długie miesiące. $\mathrm{Na}$ zachodnim brzegu rzeki Suchej okopy strony rosyjskiej ciągnęły się od nasypu kolejowego przez umocniony folwark Żylin, dzisiejszą wieś Nowa Sucha, a za nią skręcały w stronę dzisiejszej wsi Reduta Wojenna, leżącej w miejscu niezwykle silnie umocnionych pozycji określanych w 1914 i 1915 r. mianem „Las Borzymowski”. Aby skutecznie uderzyć stąd na Warszawę, armia niemiecka musiałaby zdobyć pierwszą linię okopów rosyjskich i sforsować rzekę Suchą. Wtedy jednak zadanie to wydało się dowództwu niemieckiemu trudne czy wręcz niemożliwe (patrz: Zalewska, Czarnecki, 2019).

Od lutego do maja 1915 r. linia frontu na całym odcinku rzek Rawki i Bzury ustabilizowała się i walczące strony rozpoczęły tu wojnę okopową. Front w rejonie wsi Nowa Sucha zamarł już w stycznia 1915 r. Teren ten był areną jedynie drobnych starć, podczas gdy kilka kilometrów dalej na południe, na odcinku od wsi Borzymówka (gm. loco) oraz Humin i Wola Szydłowiecka (gm. Bolimów) po Majdan Bolimowski trwała od 31 stycznia do 5 lutego wielka bitwa zimowa, która jednak Niemcom nie przyniosła przełamania frontu, a Rosjanom za cenę wielkich strat pozwoliła obronić drogę na Warszawę. Dopiero wiosną Niemcy zdecydowali się na ponowną próbę przełamania umocnień w tej okolicy przy użyciu nowej broni, tj. gazów trujących.

został pochowany (patrz: Der Direktor des Zentralnachweisamts für Kriegerverluste und Kriegergräber). 
Jeszcze w połowie grudnia 1914 r., po zajęciu Łowicza przez 9. Armię Niemiecką, powołano tam Komendę Etapów; miasto wraz ze wszystkimi zasobami zostało włączone do systemu zaopatrzenia walczącego wojska (Kaliński, 2013, s. 54). Stworzona sieć lazaretów służyła rannym i chorym, konieczne było także organizowanie pochówków poległych. Wydarzenia kolejnych dni wojny znamy bliżej dzięki wspomnianej już we wstępie Kronice dziejów Łowicza Władysława Tarczyńskiego. Można zauważyć, że miejscowości położone w pobliżu Sochaczewa (np. tworzące linię frontu Brochów - Sochaczew - Kozłów Biskupi - Bolimów) stanowią dla niego nie tyle konkretne miejsca wydarzeń wojennych - których, siłą rzeczy, nie mógł naocznie śledzić, ile raczej orientacyjne punkty lub kierunki, z których dobiegają do Łowicza odgłosy toczących się bitew i z których przywożeni są ranni. Z interesującej nas tu gminy Nowa Sucha w Kronice pojawia się jedynie nazwa „Kozłów Biskupi" (por. Tarczyński, 2015, s. 180).

Relacje Władysława Tarczyńskiego z kolejnych dni wojny pozwalają wyobrazić sobie natężenie walk i rosnącą liczbę ofiar:

Od nocy pierwszego dnia [osiemnastego] zajęcia przez Rosjan nowych pozycji za Bzurą i za Rawką, od strony Sochaczewa, a nierównie więcej od Bolimowa, dniami i nocami słychać głuche armatnie strzały, a w ciemnościach nocnych widać błyski ogniste nad pozycjami wzajemnie się uśmiercających. $Z$ tamtych też stron bardzo dużo Niemcy swych rannych przywożą, przeważnie nocami, jak też i poległych, których starannie ukrywają. (26 grudnia [1914], sobota, święto - Tarczyński, 2015, s. 188-190)

De facto armia rosyjska zaczęła zajmować pozycje na Bzurze od 15-17 grudnia. W kilka dni później Tarczyński zanotował: „Bitwa na tych samych ciągle pozycjach, pod Sochaczewem i Bolimowem, trwa nieustannie. Huk armat słychać i błyski ogniste widoczne były wczoraj wieczorem w stronie Kutna. Rannych z pozycji przywożą codziennie dużymi partiami”" (11 stycznia [1915], poniedziałek - Tarczyński, 2015, s. 198). Opisane wydarzenia były próbą przełamania przez 9 . Armię Niemiecką rosyjskiej linii obronnej w okolicach przyczółka na Bzurze pod Kozłowem Biskupim.

Następne dni, w które daje wgląd relacja zawarta w Kronice Łowicza, skutkowały kolejnymi śmiertelnymi ofiarami wojny: „Kanonada bardzo silna i nieustannie grzmi na linii bojowej, jakby od strony Kozłowa do Sochaczewa" (24 stycznia [1915], niedziela - Tarczyński, 2015, s. 216) czy „Kanonada mniejsza, strzały armatnie słychać słabsze, z dalszej odległości. Niemcy zza Rybna strzelają na Sochaczew, gdzie są Rosjanie" (27 stycznia [1915], środa - Tarczyński, 2015, s. 219).

Ciągłe walki powodowały coraz większe straty w ludziach, co obserwowała ludność zamieszkująca tereny położone na zapleczu frontu. Uwadze mieszkańców Łowicza nie uchodziły m.in. zabiegi niemieckich władz wojskowych, które prowadziły swoistą politykę dezinformacji przez niepodawanie danych na temat strat własnych. Służyć to mogło podtrzymaniu morale wojska i szerzeniu wśród miejscowej ludności przekonania o skuteczności armii niemieckiej. Taki m.in. przekaz zawiera 
zapis Tarczyńskiego z 31 stycznia o tym, że Niemcy „wywożą rannych do Prus”, co „utrzymują w tajemnicy, jak również ukrywają poległych swoich, a szczególnie ich liczbę”, zaś „na pobojowiskach, na zagrzebanych trupach, równają ziemię dla zatarcia śladu" (patrz: Tarczyński, 2015, s. 229-230, por. pełny cytat w: Zalewska, Cyngot, 2017, s. 135).

Utrzymywanie przez armię niemiecką w tajemnicy sytuacji na froncie stopniowo nasilało się. Dotyczyło to zwłaszcza szczególnie starannie zaplanowanego ataku, który miał miejsce w 31 stycznia 1915 r.:

W wielkiej bitwie, toczącej się już od dłuższego czasu, w ciągu jednej doby 31 [stycznia] - 1 [lutego] na linii Bolimów - Sochaczew, Niemcy na pozycje rosyjskie wyrzucili pocisków 40 000, usiłując wyprzeć Rosjan z zajmowanych przez nich pozycji. Rezultat niewiadomy; to pewne, że oni sami ponieśli wielkie straty. Trupów legły stosy, a rannych rozwieźli po okolicznych wioskach i tu do miasta przywieźli wielką liczbę. Doby owej rzęsisty grad kul, ten huragan piekielny nad wszelkie wyobrażenie był straszny! Okropny! Wśród rannych Rosjan, oficer i żołnierz popadli w obłęd. (1 lutego [1915], poniedziałek - Tarczyński, 2015, s. 231, por. też zapis z 6 lutego 1915 roku; 2015, s. 237; omówienie także w: Zalewska, Cyngot, 2017, s. 126)

Elementem tej ofensywy niemieckiej była pierwsza próba masowego użycia gazów bojowych. Nastąpiła ona w czasie trwania bitwy między 31 stycznia a 5 lutego 1915 r. W jej trakcie Niemcy wystrzelili 18000 pocisków z gazem łzawiącym. Natarcie 9. Armii Niemieckiej poprzedził kilkugodzinny ostrzał artylerii. Niemcy w jego trakcie użyli broni masowego rażenia w postaci pocisków chemicznych typu „T" i „Ni”, zawierających bromek ksylilu (T-Stoff) i dwuanizydynę (Ni-Stoff) o działaniu łzawiącym i duszącym (niemieccy żołnierze nazywali je „bombami śmierdzącymi”) $)^{2}$ W trakcie ataków używano też miotaczy płomieni zwanych „ognistymi językami”. Liczne wspomagane przez artylerię ataki i kontrataki z początku lutego w rejonie pomiędzy Borzymowem i Kurabką poskutkowały ogromnymi stratami ludzkimi po obydwu stronach.

Data 31 stycznia 1915 r. powszechnie dotychczas w historiografii traktowana była jako dzień pierwszego użycia broni masowego rażenia w sytuacji bojowej. Ale, jeśli potraktować wiążąco zapisy z Dziennika Działań Bojowych 9. Armii Niemieckiej poddane analizie $\mathrm{w}$ trakcie jednej $\mathrm{z}$ kwerend archiwalnych APP wykonanych przez A. I. Zalewską i J. Czarneckiego, to pociski chemiczne „Ni” użyto prawdopodobnie już w 1 połowie stycznia 1915 r. w okolicy folwarku Mogiły, jednak dziennik nie podaje na ten temat żadnych szczegółów (zagadnienie to zostało omówione w innym miejscu: Zalewska 2019a, tam też dalsza literatura). Więcej natomiast wiemy na temat użycia pocisków „,”. Wydano je artylerzystom 15 stycznia 1915 r.,

\footnotetext{
${ }^{2}$ Według współczesnej terminologii oba środki należałyby do kategorii bojowych środków pomocniczych (BSP).
} 
zaś do ich próbnego użycia doszło już 16, 23 i 26 stycznia 1915 r. (por. Zalewska, Czarnecki, 2016, s. 25-31, szczegóły patrz: Zalewska, 2019a). W Dzienniku Działań Bojowych 9. Armii odnotowano jedynie krótką analizę skutków użycia gazów łzawiących, m.in. to, że o ile samo działanie gazu było przez stronę niemiecką oceniane „korzystnie”, to cały atak nie przyniósł oczekiwanego efektu, nie zdobyto bowiem rosyjskich pozycji (za: Kriegstagebuch...).

Natychmiastowe przejęcie okopów okazało się niewykonalne, ,ponieważ gaz utrzymywał się za długo”, ale „wycofywanie się przeciwników w popłochu z okopów" stwarzało okazje „do owocnego wykorzystania” pocisków gazowych (za: Kriegstagebuch). Można przyjąć, że miało to wpływ na fakt, że dowództwo niemieckie pokładało tak wielkie nadzieje w broni chemicznej, co skutkowało zastąpieniem bojowych środków pomocniczych (gazów łzawiących i drażniących) - bojowymi środkami trującymi, tj. chlorem (por. Kaliński, 2015; Zalewska, Czarnecki, 2016, s. 28-33, 54-96; Zalewska, 2019a).

Następne potyczki na omawianym tu odcinku walk następowały z przerwami. Ich symptomami zauważalnymi na zapleczu frontu były kolejne transporty rannych żołnierzy i jeńców oraz nałożenie tajemnicy na wszelkie informacje o toczących się walkach, co - jak to odbierano w mieście etapowym Łowiczu - powodowało efekt zastraszenia:

Wczoraj przybyła partia świeżo rannych Niemców, stamtąd, gdzie była bitwa. W którym punkcie linii bojowej? Dowiedzieć się, rzecz niepodobna, taka tajemnica i nią skrępowani są żołnierze, pytać się jest niebezpiecznie, za to grozi kara surowa. O ile słychać strzały, wiadomo, że jest bitwa, a gdzie, tylko miarkować można po głosie, ale to zawodzi. Wiadomo ogólnie i z odgłosów strzałów, że na linii Bolimów - Sochaczew i tam dalej, ku Wiśle. Z okopów ciągle strzelają do siebie, niekiedy atakują się wzajemnie, i wtedy są większe ofiary i rannych bywa dużo. Rannych swoich bardzo dużo wywieźli do Prus, w kilku domach szpitale są opróżnione. Rannych jeńców rosyjskich także wywożą raz po raz, świeżych nie przybyło w tych dniach. (21 lutego [1915], niedziela - Tarczyński, 2015, s. 266-267)

Rannych żołnierzy, zapewne ze względu na ich dużą liczbę, rozprowadzano nie tylko po lazaretach położonych stosunkowo blisko pola walki, ale także wysyłano ich dalej (14 marca [1915], niedziela - por. Tarczyński, 2015, s. 294).

Mimo że niemieckie władze wojskowe utrudniały zasięganie informacji o wydarzeniach frontowych i o stratach ponoszonych w walkach, ludność okolicznych miejscowości próbowała wyrobić sobie miarodajną ocenę sytuacji, w której przyszło jej uczestniczyć. Trudno podać podstawę, z której wyrastały szacowane liczby poległych żołnierzy przekazywane sobie przez mieszkańców Łowicza: „Od czasu jak toczą się bitwy, tj. od 17 grudnia ubiegłego roku, w okolicy Skierniewic, Radziwiłłowa i Rawy, ludzie świadomi rzeczy obliczają poległych Niemców do 200 tysięcy. Zaś na linii od Wisły na Sochaczew - Bolimów ku Skierniewicom - 125 ty- 
sięcy” (24 marca [1915], środa - Tarczyński, 2015, s. 304-305, por. też Zalewska, Cyngot, 2017, s. 123-124).

Najcięższe walki z opisywanego wówczas przez Tarczyńskiego okresu miały miejsce na odcinku Sochaczew - Skierniewice. Na południe od Skierniewic i na północ od Sochaczewa front był dużo spokojniejszy. Dane odnoszące się do liczby poległych trudno uznać za wiarygodne, gdy skonfrontujemy je z zapisami dokumentów niemieckich. Trudno jednak dziś wiążąco je skorygować. Dokumentacja archiwalna nie jest pełna, przez co wyliczane na jej podstawie straty ludzkie pozostają ramową estymacją. Jednak nawet niepełne dane ukazują nam, że straty strony niemieckiej były niższe od strat po stronie rosyjskiej, a te ostatnie, na przykład w czasie najkrwawszej bitwy od 31 stycznia do 5 lutego, nawet Rosjanie określili na około 40000 żołnierzy (zabitych, rannych i zaginionych). Tak znaczne straty żołnierzy niemieckich (jak dane przywołane powyżej przez Tarczyńskiego, za „świadomymi rzeczy" ludźmi) nie znajdują też potwierdzenia na odnalezionych dotychczas cmentarzach oraz w rozpoznanej w ramach APP dokumentacji z okresu między wojnami. Opis wyolbrzymionych strat przedstawiony przez Tarczyńskiego rzuca jednak światło na nastroje panujące wśród ludności, choćby to, że traktowano Niemców jak wrogów (gdy mowa o zastraszeniu) i wyolbrzymiano ich straty (być może „ku pokrzepieniu serc"?).

Notowane przez Tarczyńskiego wydarzenia wojenne z kolejnych miesięcy walk różnią się jedynie drobnymi szczegółami i wydają się wręcz monotonne, o ile można użyć takiego sformułowania w odniesieniu do relacji z toczącej się wojny. Jednak to właśnie takie jednostkowe relacje świadków naocznych, podobnie jak rozproszone fragmenty informacji znajdowane na mapach czy w zapiskach archiwalnych, uzupełniają nasz wgląd w przestrzeń i czas wojny o szczegóły dotyczące rannych i poległych. Jest to świadectwo o tyle bezcenne, że stanowi uzupełnienie obrazu wydarzeń i dodaje wyrazistości faktom znanym ramowo z opracowań historycznych i ze źródeł archiwalnych, ujętym między innymi w pamiętnikach czy w nieco wyidealizowanych (wydawanych w latach 20. i 30. XX wieku) historiach pułków armii niemieckiej biorących udział w walkach nad Rawką i Bzurą. Zapisy dotyczące specyfiki stabilizowania się linii frontu wzdłuż biegu Rawki i Bzury przez kilka miesięcy walk są w nich na ogół podane lakonicznie, zwłaszcza gdy odnoszą się do kwestii poległych i miejsc ich spoczynku, szczególnie w okresach tzw. stagnacji działań wojennych (zagadnienie to uszczegóławiamy w innym miejscu, patrz: Zalewska, Czarnecki, 2019).

Od marca do maja front wydawał się być uśpiony, ale jedynie doraźnie, tj. do 31 maja 1915 r., gdy po raz pierwszy na froncie wschodnim strona niemiecka właśnie na tym odcinku użyła śmiercionośnego chloru. Niemcy wypuścili w stronę linii rosyjskich około 240 ton gazu. Chlor umieszczony był w stalowych butlach, a te wkopano w dno okopów od Majdanu Bolimowskiego aż po Zakrzew. Trująca chmura została porwana przez wiatr i przeniesiona nad pierwszą linią okopów wroga. Obsadzający 
majątek Zakrzew żołnierze 48 Rezerwowego Pułku Piechoty 9. Armii Niemieckiej po wypuszczeniu gazu z butli słyszeli dochodzące z rosyjskich okopów rzężenie duszących się ludzi. Gdy jednak żołnierze armii niemieckiej ruszyli do ataku, spadł na nich grad rosyjskich pocisków karabinowych, a to dlatego, że na pewnych odcinkach frontu wiatr tak pokierował chmurą trującego gazu, że żołnierze rosyjscy w pierwszej linii nie zginęli od razu, ale ulegli (początkowo) tylko lekkiemu zatruciu i mogli dalej walczyć. Dlatego armia niemiecka nie zdołała również tego dnia przełamać linii rosyjskich, mimo że na dalszych pozycjach gaz dokonał prawdziwego spustoszenia w szeregach armii rosyjskiej - o czym nie wiedziano po stronie przeciwnej.

Po tym doświadczeniu niemieckie dowództwo uznało, że gazu trzeba użyć na krótszym odcinku, a natarcie wesprzeć artylerią. Dlatego 12 czerwca 1915 r. wypuszczono trującą chmurę jedynie na odcinku $6 \mathrm{~km}$, na linii Zakrzew - Sucha - Las Borzymowski (dziś Reduta Wojenna, tj. w granicach administracyjnych dzisiejszej gminy Nowa Sucha).

Zanim otwarto zawory butli, niemiecka artyleria ostrzelała rosyjskie pozycje huraganowym ogniem. Gaz był bronią nieprzewidywalną - uzależnioną od zmienności kierunku wiatru. Przekonali się o tym właśnie w dorzeczu rzeki Suchej (tj. na terenie dzisiejszej gminy Nowa Sucha) żołnierze armii niemieckiej (wśród nich bardzo liczni Polacy), m.in. żołnierze 128. Gdańskiego Pułku Piechoty. W momencie gdy wychodzili z okopów do szturmu, zmienił się kierunek wiatru i chmura gazu raziła szeregi atakujących, by po chwili znowu popłynąć w stronę okopów armii rosyjskiej. Pierwsza linia rosyjska została przerwana prawie bez walki. Tym razem artyleria i broń chemiczna sprostały oczekiwaniom Niemców, którzy zdobyli Zakrzew, Suchą i Kozłów Biskupi.

Straty wojsk rosyjskich były znaczące (ryc. 2). Według ustaleń niemieckiego wywiadu gaz zabił na miejscu około 1200 żołnierzy armii carskiej, a ponad 3100 zatrutych odwieziono do szpitali. Całkowita liczba ofiar czerwcowego ataku pozostaje nieznana, wiadomo jednak, że również armia niemiecka poniosła wówczas straty: od 500 do 700 żołnierzy zostało zabitych lub rannych, w tym gaz zatruł około 350 żołnierzy (szerzej temat czerwcowego ataku został omówiony w innym miejscu, patrz: Zalewska, Czarnecki, 2016, s. 91-96; Kaliński, 2015).

Polegli w tej okolicy spoczęli m.in. na cmentarzu parafialnym w Kozłowie Szlacheckim (ryc. 3: NS4) oraz na licznych zapomnianych cmentarzach wojennych. Jednym z takich miejsc jest, odkryty w toku badań „Archeologicznego Przywracania Pamięci o Wielkiej Wojnie", cmentarz w Lesie Kozłowskim (o którym piszemy dalej), gdzie na nielicznych zachowanych tablicach nagrobnych są, ledwo już widoczne, obok nazwisk i przynależności pułkowej poległych żołnierzy, również daty ich śmierci - właśnie z czerwca 1915 r. (por. Zalewska, Czarnecki, 2016, s. 117). Cmentarz ten wciąż czeka na proces „odpomnienia”. Mamy nadzieję, że prowokację i podstawę do tego „odpomnienia” stanowić mogą wyniki uzyskane przez archeologiczne przywracanie pamięci o Wielkiej Wojnie (APP) zaprezentowane poniżej. 


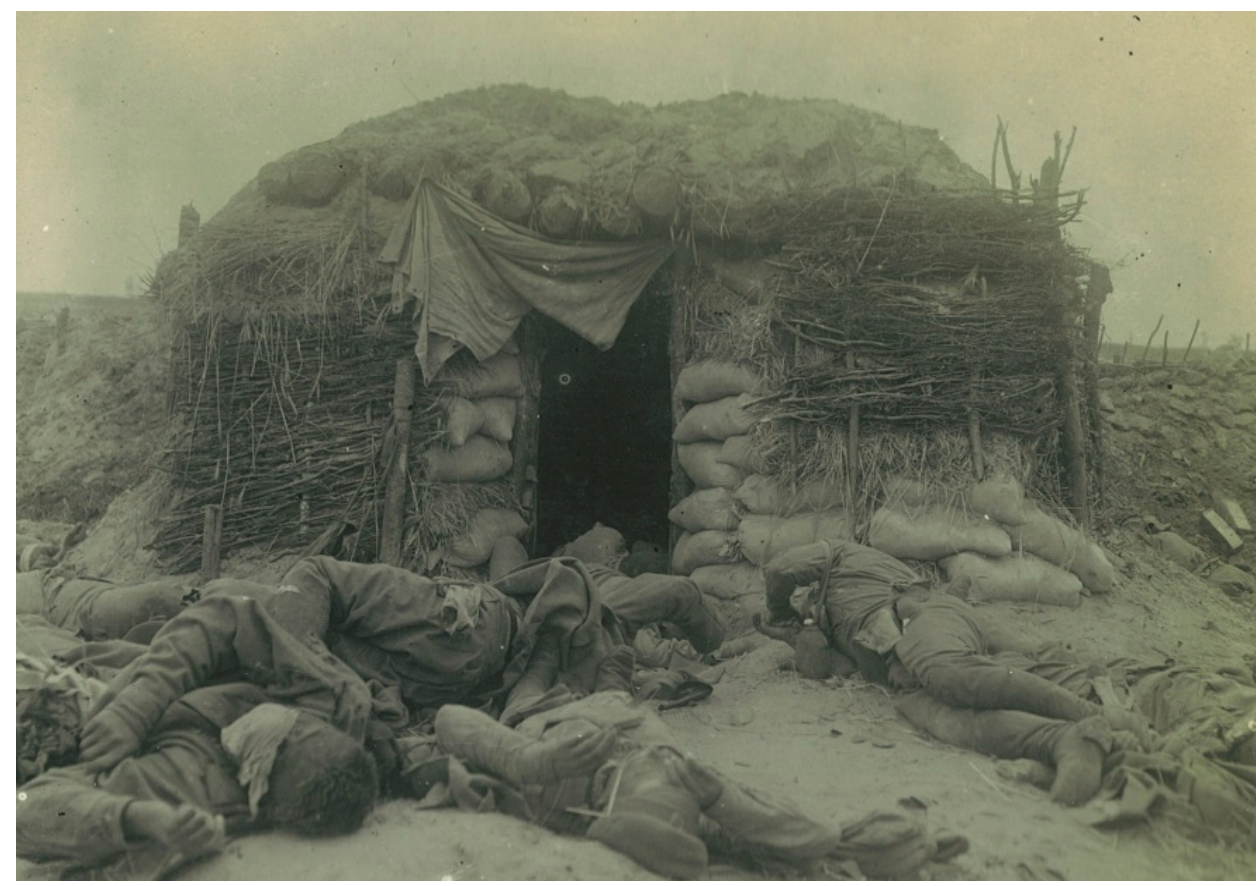

Ryc. 2. Żołnierze armii rosyjskiej uduszeni chlorem w pobliżu wsi Sucha, 12 czerwca 1915 (z kolekcji J. Czarneckiego).

Fig. 2. Soldiers of the Russian army suffocated with chlorine near the village of Sucha, June 12, 1915 (from the private collection of J. Czarnecki).

Dotychczas na poziomie lokalnym proces przywracania pamięci o Wielkiej Wojnie został zainicjowany w centrum miejscowości Nowa Sucha, tj. w przestrzeni, w której doszło do użycia broni masowego rażenia w czerwcu 1915 r., oraz w Borzymówce, gdzie z inicjatywy Fundacji Przydrożne Lekcje Historii postawione zostały tablice informacyjne, będące wynikiem projektu pt. „Archeologia pojednania. Przydrożne lekcje historii na temat wielkiej wojny nad Rawką (1915-2015)" (kierownik prospołecznego projektu edukacyjnego: A. I. Zalewska), zrealizowanego przez Fundację Przydrożne Lekcje Historii, przy finansowym wsparciu Fundacji Współpracy Polsko-Niemieckiej.

Tablice te są częścią zainicjowanego przez Fundację Przydrożne Lekcje Historii szlaku turystycznego wiodącego przez miejsca naznaczone walkami - od Puszczy Bolimowskiej po Nową Suchą (więcej informacji na temat wyników tego projektu oraz działań wojennych i materialnych po nich pozostałości znajduje się w publikacji, w której w przystępny sposób staraliśmy się zawrzeć argumenty przemawiające za potrzebą poznania wydarzeń sprzed stu lat oraz za uczytelnianiem zapisanych w pamięci krajobrazu materialnych po nich śladów - które mogą pełnić funkcje materialnych przestróg dla współczesnych (patrz: Zalewska, Czarnecki, 2016). 


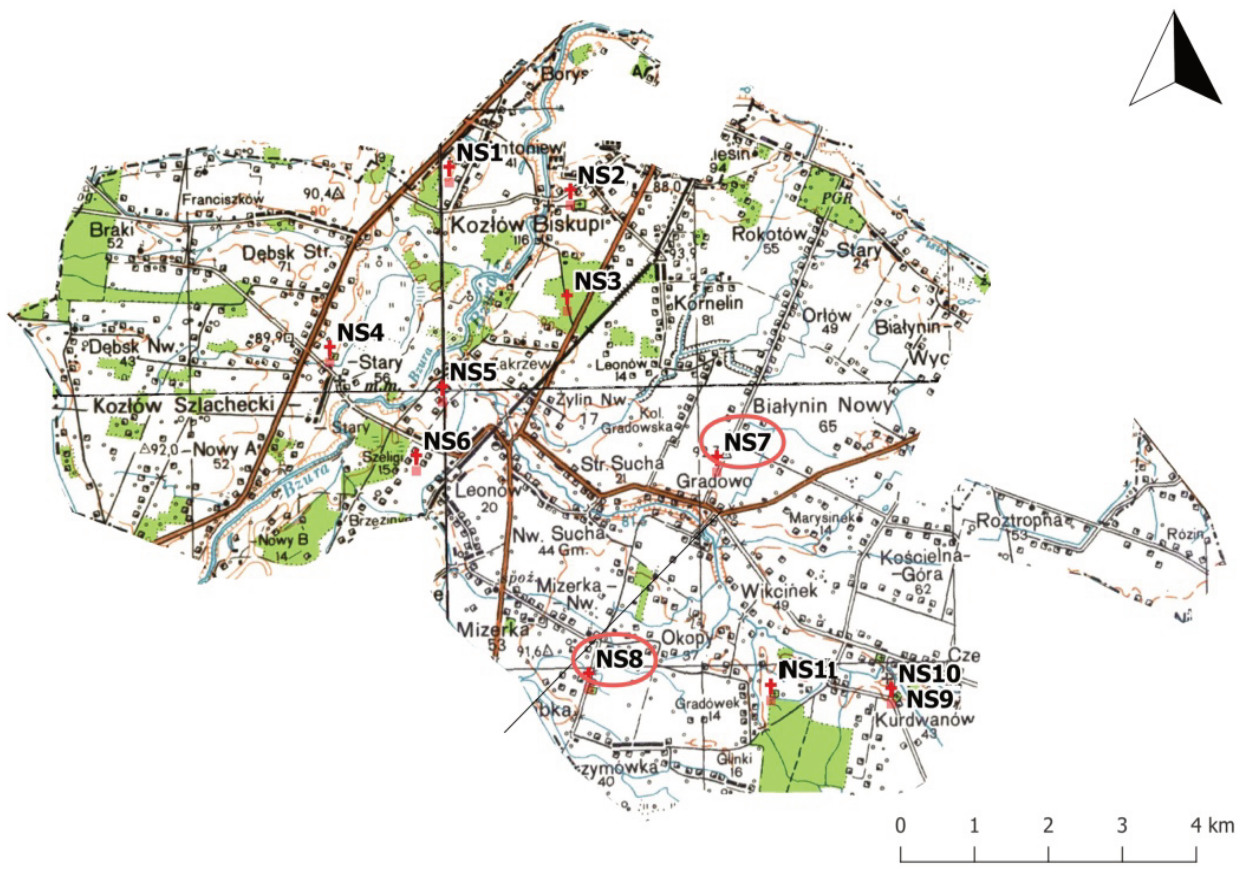

Projekt Naukowy: Archeologiczne Przywracanie Pamięci o Wielkiej Wojnie. Materialne pozostałości życia i śmierci w okopach na froncie wschodnim oraz stan przemian krajobrazu pobitewnego w rejonie Rawki i Bzury (Akronim Projektu - APP)

Kierownik projektu: dr hab. Anna I. Zalewska Nr projektu: NCN - Sonata BIS - nr 2013/10/E/ HS3/00406

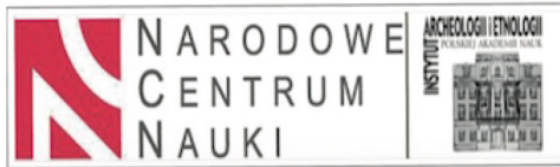

\section{Miejsca posiadające cechy cmentarza wojennego (CW) $z$ okresu I wojny światowej i rozpoznane $w$ toku projektu APP w latach 2014-2017:}

- oznaczenie zlokalizowanych cmentarzy wojennych z okresu Wielkiej Wojny

- cmentarze wojenne z okresu I wojny światowej wpisane do Gminnej Ewidencji Zabytków (GEZ) uprzednio, niezależnie od badań archeologicznych

Ryc. 3. Lokalizacja miejsc spoczynku żołnierzy poległych w latach 1914-1915. Cmentarze wojenne z okresu pierwszej wojny światowej, które zostały rozpoznane w toku projektu APP w latach 2014-2017 w aktualnych granicach administracyjnych gminy Nowa Sucha (Dane z bazy danych projektu APP, opracowanie A. I. Zalewska, G. Kiarszys).

Fig. 3. Location of resting places of soldiers fallen in the years 1914-1915. War cemeteries from the period of the First World War, which were recognized within the current administrative borders of the commune of Nowa Sucha during the ARM project in 2014-2017 (ARM's Data Base, designed by A. I. Zalewska, G. Kiarszys).

Również cmentarze wojenne, na których spoczęli żołnierze Wielkiej Wojny polegli m.in. w czerwcowym ataku gazowym, pozostają niemą materialną przestrogą odnoszącą się do długiej, złożonej historii technologizacji wojny czy do użycia broni masowego rażenia przez człowieka; broni, która do niedawna pozostawała całkowicie 
zapomnianym „epizodem” frontu wschodniego Wielkiej Wojny (por. Ludendorff, 1919 [2014]; De-Lazari, 1935; Martinez, 1996; Zalewska, 2013, 2016b; Kaliński, 2015).

Czerwcowy atak gazowy nie doprowadził do radykalnych zmian w sytuacji walczących armii. Działania wojenne w rejonie Rawki i Bzury, w tym na terenie dzisiejszej gminy Nowa Sucha, zakończyły się nocą z 16 na 17 lipca 1915 r. Wojska armii rosyjskiej opuściły fortyfikacje polowe, udając się na wschód w stronę Warszawy. W ślad za nimi ruszyły wojska armii niemieckiej.

Po działaniach wojennych pozostały zgliszcza wsi, dóbr ziemskich i osad, poranione okopami i śladami ostrzałów pola, wyniszczone sady, ogrody i lasy oraz miejsca spoczynku poległych żołnierzy, których lokalizacja po stu latach wymagała zaangażowania metod archeologicznych skorelowanych z badaniami archiwalnymi i teledetekcyjnymi.

Poniżej przedstawiamy odnoszące się do cmentarzy wojennych z obszaru gminy Nowa Sucha wyniki zakończonego właśnie etapu procesu poznawczego w ramach projektu APP, którego zasadnicze cele obrane w 2013 r. to:

1) przywrócenie pamięci o froncie wschodnim I wojny światowej i pobudzenie refleksji nad wartością i ewentualną sprawczością krajobrazów naznaczonych wojną jako materialnych przestróg;

2) zaktualizowanie wyobrażeń o uczestnikach walk, o specyfice i następstwach działań zbrojnych w centralnej Polsce;

3) wzbogacenie wiedzy o życiu i śmierci żołnierzy w okopach Wielkiej Wojny;

4) zapewnienie godnego pochówku szczątkom poległych odnalezionym na polu bitwy oraz zlokalizowanie i zdelimitowanie zapomnianych cmentarzy wojennych;

5) zadokumentowanie i interpretacja aktualnego stanu zachowania szczególnego krajobrazu pogazowego, stanowiącego kontekst inicjacji bojowego użycia broni chemicznej;

6) objęcie ochroną i konserwacją unikalnych materialnych reliktów Wielkiej Wojny rozpoznanych $w$ trakcie archeologicznego przywracania pamięci, zwłaszcza na terenie Puszczy Bolimowskiej, oraz w odniesieniu do miejsc spoczynku poległych żolnierzy (szerzej na ten temat zob. Zalewska, 2017, s. 61-67).

\section{LOKALIZACJA CMENTARZY WOJENNYCH W RAMACH ARCHEOLOGICZNEGO PRZYWRACANIA PAMIECI O WIELKIEJ WOJNIE}

Powierzchnia gminy omawianej tu pod względem obecności cmentarzy i mogił wojennych jednostki administracyjnej, tj. gminy Nowa Sucha (od 1998 r. znajdującej się w granicach administracyjnych powiatu sochaczewskiego) wynosi 90,34 km kw., 
z czego $85 \%$ stanowią użytki rolne ${ }^{3}$. Znaczne przekształcenie powierzchni terenu na przestrzeni ostatnich stu lat, tj. od zakończenia działań związanych z pierwszą wojną światową oraz $\mathrm{z}$ czasem podnoszenia infrastruktury tego obszaru $\mathrm{z}$ ruin, spowodowało, że aktualnie można tam zaobserwować jedynie nieliczne relikty materialne z okresu wojny 1914-1918. Na omawianym tu terenie są również obecne cmentarze wojenne napowierzchniowo czytelne, a jednak niemal zapomniane - (nie)obecne (por. cmentarz wojenny w kształcie podkowy w miejscowości Gradów NS7) (ryc. 4).

Wtórne przekształcenia krajobrazu są zaledwie jednym z kilku istotnych powodów, które przełożyły się na trudności ze zlokalizowaniem cmentarzy Wielkiej Wojny w centralnej Polsce. To suma tych procesów spowodowała, że na terenie gminy Nowa Sucha, stanowiącej tu ramy przestrzenne omówienia problematyczności założenia, że troska o cmentarze wojenne winna być bezczasowo traktowana jako „czysto ludzka sprawa”, za cmentarze wojenne z okresu I wojny światowej uważane były w sensie formalnym, czyli wpisane do Gminnej Ewidencji Zabytków (GEZ), zaledwie dwa następujące miejsca (oznaczone na mapie symbolami NS7 i NS8, zob.: ryc. 3):

1) Cmentarz wojenny z I wojny światowej. Adres: 96-513 Marysinek/Wikicinek, Nr. działki geodez.: 63 (Marysinek) oraz 17 (Wikicinek) (ryc. 3: NS7);

2) Cmentarz wojenny z I wojny światowej. Adres: 96-513 Borzymówka, Nr. działki geodez.: 20 (ryc. 3: NS8).

Warta podkreślenia jest okoliczność, że żaden z cmentarzy wojennych z terenu gminy Nowa Sucha nie miał choćby tzw. Karty Cmentarza (i/lub Karty Miejsca Pamięci Narodowej) w Mazowieckim Urzędzie Wojewódzkim w Warszawie (stan do grudnia 2016 r.). Jednocześnie, według Wykazu zabytków wpisanych do rejestru zabytków nieruchomych woj. mazowieckiego (aktualizacja z marca 2018 r.), na terenie gminy Nowa Sucha nie znajdował się żaden otoczony opieką cmentarz wojenny (https://www.nid.pl/pl/Informacje_ogolne/Zabytki...).

W wyniku Archeologicznego Przywracania Pamięci o Wielkiej Wojnie źródłowo rozpoznanych zostało 21 miejsc wyczerpujących przedmiotową definicję cmentarzy wojennych, tj. - zgodnie z art. 1.1, p. 2 Ustawy o grobach i cmentarzach wojennych z dnia 28 marca 1933 r. - takich, na których pochowani zostali wojskowi, polegli lub zmarli z powodu działań wojennych, bez względu na narodowość ${ }^{4}$ (patrz: tabela 1).

\footnotetext{
${ }^{3}$ Gmina Nowa Sucha graniczy z ośmioma gminami: Bolimów, Kocierzew Południowy, Nieborów, Rybno, Sochaczew (gmina), Sochaczew (miasto), Teresin oraz Wiskitki. Dwie spośród tych gmin, tj. Bolimów i Nieborów również stanowiły przedmiot badań APP $w$ odniesieniu do materialnych reliktów Wielkiej Wojny, a problemy odnoszące się m.in. do cmentarzy wojennych z terenu tych gmin zostały opisane w innym miejscu, zob. nt. gminy Bolimów w: Zalewska, 2013; Zalewska, 2016b; Zalewska, Kiarszys, 2017; Zalewska, Cyngot, 2017 oraz nt. gminy Wiskitki w: Zalewska, Cyngot, Czarnecki, Kiarszys, 2018.

${ }^{4}$ Pełna lista cmentarzy wojennych, włącznie z odnotowanymi w przekazach źródłowych, ale nie zlokalizowanymi w terenie, zostanie zawarta w publikacji podsumowującej projekt APP. Bardzo istotny
} 


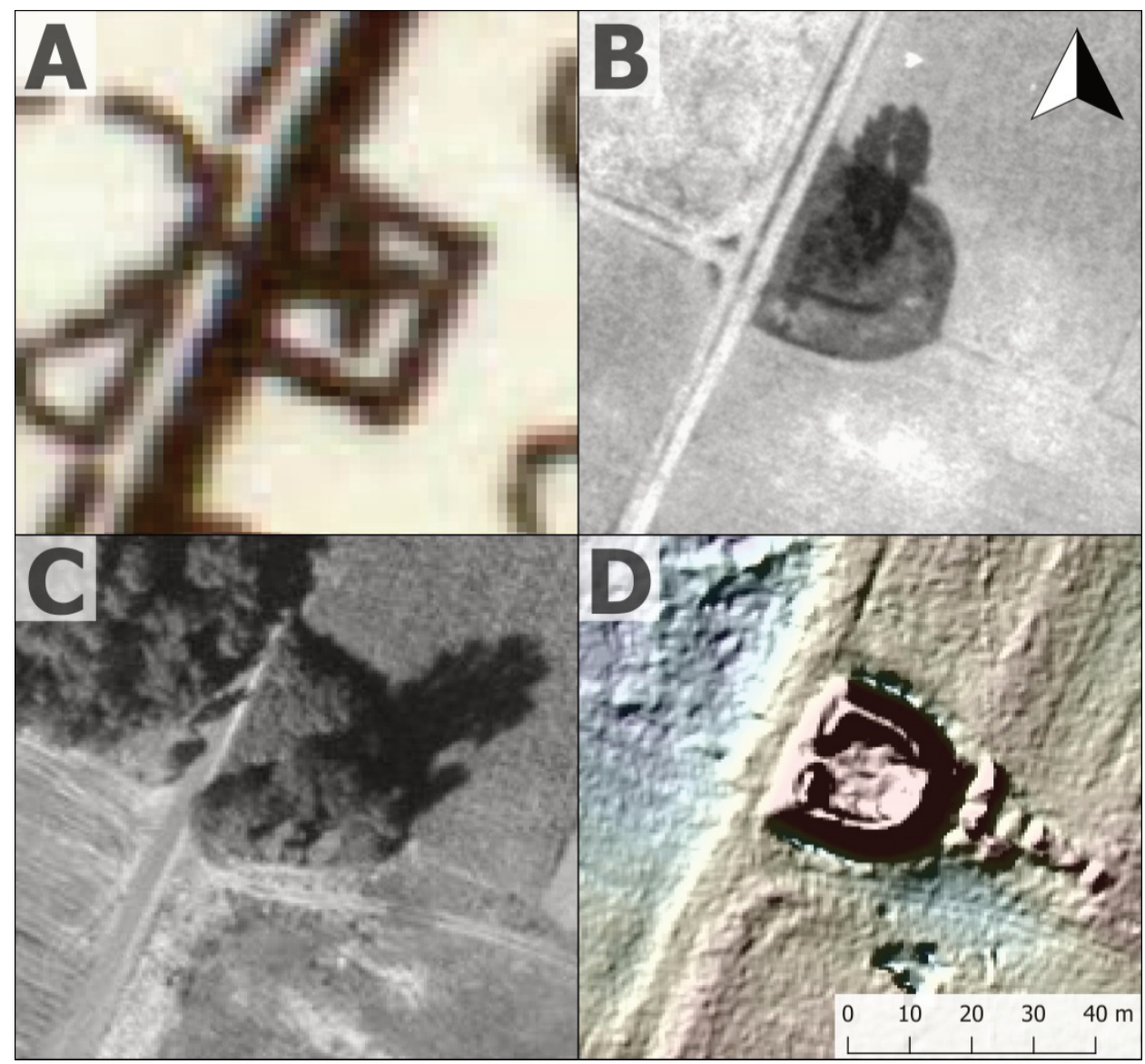

Ryc. 4. Cmentarz w kształcie podkowy w miejscowości Gradów (NS7), gm. Nowa Sucha: A - Mapa topograficzna WIG z 1943 r. (oryginalna skala 1:25 000); B - Zdjęcie lotnicze z 1964 r.; C - Zdjęcie lotnicze z 2004 r.; D - Pochodna numerycznego modelu terenu z danych ALS (kompozycja analizy cieniowania i NMT) (Dane z bazy danych projektu APP, opracowanie G. Kiarszys).

Fig. 4. The semicircle-shaped cemetery in Gradów (NS7), commune Nowa Sucha: A - Topographic map of WIG from 1943 (original scale $1: 25,000$ ); B - Aerial photograph from 1964; C - Aerial photograph from 2004; D - The derivative of the numerical terrain model from ALS data (composition of shading analysis and NMT) (ARM's Data Base, designed by G. Kiarszys).

$\mathrm{Z}$ archeologicznego punktu widzenia cechą przekazów archiwalnych (co nie podważa absolutnie siły słowa pisanego i zapisów źródłowych rozpoznanych przez nas w toku APP, ale ukazuje ich specyfikę) jest ich znikome osadzenie w realnej przestrzeni (za: Zalewska, Cyngot, 2017, s. 147-148). Było to istotnym powodem do

udział w rozpoznaniu archiwaliów niemieckich miała Małgorzata Karczewska, która w ramach realizacji celów projektu APP wykonała kwerendy w zasobach archiwalnych Ministerstwa Spraw Zagranicznych oraz Volksbund Deutsche Kriegsgräberfürsorge e.V. z lat 1923-1939. 
podjęcia prób lokalizowania miejsc funeralnych Wielkiej Wojny z użyciem metod archeologicznych, teledetekcyjnych i etnoarcheologicznych, również w odniesieniu do obszaru gminy Nowa Sucha, gdzie dominują grunty rolne. Są to głównie niewielkie indywidualne pola należące do prywatnych właścicieli. Występują także stosunkowo nieliczne lasy i nieużytki o niewielkiej powierzchni. Taki sposób wykorzystywania terenu miał istotny wpływ na aktualny stan zachowania cmentarzy wojennych z okresu I wojny światowej. Już w niedługim czasie po zakończeniu działań wojennych grunty, na których obecne były materialne relikty wydarzeń wojennych z lat 1914-1915, zostały poddane stopniowej rekultywacji, a miejsca po ekshumowanych i przenoszonych cmentarzach były sukcesywnie przekształcane w użytki leśne (jak w przypadku terenu cmentarza w Kozłowie Biskupim), rolne (większość pozostałych cmentarzy) i przemysłowe (jak w odniesieniu do cmentarza w Antoniewie).

Wyjątkowość archeologii opiera się między innymi na tym, że daje ona wgląd nie tylko w aktualny stan rzeczy, ale także pozwala śledzić wyraźnie czytelne w krajobrazie procesy wtórne, których skutkiem jest właśnie aktualny stan rzeczy. Jest to możliwe przy zastosowaniu szerokiego wachlarza metod, których rezultaty dzięki ich zintegrowaniu w bazie danych Systemu Informacji Geograficznej (SIG/GIS, ang. Geographic Information System) pozwoliły nam z jednej strony na zarejestrowanie/lokalizację nawet tych elementów krajobrazu (w tym wypadku związanych z działaniami wojennymi z okresu I wojny światowej), których obecność jest jedynie oznakowa, $\mathrm{z}$ drugiej zaś strony umożliwiły łączenie tych elementów w związki przyczynowo-skutkowe, wzbogacając naszą wiedzę m.in. o bardzo złożonym fenomenie, jakim jest krajobraz wojny, w tym jego trwające w czasie, podlegające permanentnej transformacji materialne pozostałości.

Analizując zarówno kontekst historyczny wydarzeń wojennych z lat 1914-1915, w tym intensywność przekształceń krajobrazu, do jakich musiało wówczas dojść, jak i masowość śmierci żołnierzy, którzy w toku walk polegli i spoczęli w kontekście fortyfikacji polowych, doszliśmy do wniosku, że niemal całkowity brak czytelnych na powierzchni reliktów Wielkiej Wojny na niektórych obszarach nie może być traktowany jako równoznaczny z ich nieobecnością.

Gromadzone podczas realizacji projektu APP zasoby danych niezmiennie postrzegaliśmy jako obarczone „błędem przeżywalności” (ang. survivorship bias lub survivor bias), co skutecznie pomogło nam unikać pokusy opierania się na zastanych interpretacjach i stanie wiedzy (z których, jak w odniesieniu do omawianego tu zagadnienia, mogło wynikać, że na terenie, gdzie poległy dziesiątki tysięcy żołnierzy, niemal nie ma już cmentarzy wojennych). Wyszliśmy z założenia, że z wielu powodów dane zastane mogą być niereprezentatywne dla ontologicznego stanu rzeczy (Morgenstern, 1951; Wolfowitz, 1952; Hauser, 2007, s. 176-180). W związku z tym przyjęliśmy, że pewne wskazanie takich miejsc, które mogą być utożsamiane z przedmiotową definicją cmentarzy wojennych, możliwe jest wówczas, gdy co najmniej dwie przesłanki (zasoby informacji) wskazują na ich obecność i pozwalają na najbardziej prawdopodobną lokalizację. 
W wyniku korelacji danych archiwalnych, teledetekcyjnych i archeologicznych, spośród 21 cmentarzy wojennych i mogił wojennych odnalezionych w aktualnych granicach administracyjnych gminy Nowa Sucha (tabela 1) w toku APP zlokalizowanych zostało dotychczas 11 cmentarzy z okresu Wielkiej Wojny (NS1-11, gdzie NS to akronim nazwy gminy, patrz: ryc. 3, tabele 1 i 2).

Tabela 1. Cmentarze wojenne we współczesnych granicach administracyjnych gminy Nowa Sucha (wg. kolejności alfabetycznej) rozpoznane na postawie kwerend archiwalnych

Table 1. War cemeteries in the contemporary administrative boundaries of the commune of Nowa Sucha (in alphabetical order) recognized on the basis of archival queries

\begin{tabular}{|c|c|c|c|c|c|c|}
\hline L.p. & $\begin{array}{l}\text { Nazwa miejscowości } \\
\text { (gm. Nowa Sucha) }\end{array}$ & $\begin{array}{l}\text { Liczba } \\
\text { pocho- } \\
\text { wanych }\end{array}$ & $\begin{array}{l}\mathrm{R}-\text { armia } \\
\text { rosyjska } \\
\mathrm{N}-\text { armia } \\
\text { niemiecka }\end{array}$ & $\begin{array}{l}\text { Wtórne przekształcenia miejsc spoczynku } \\
\text { (ekshumacje, komasacje etc.) }\end{array}$ & $\begin{array}{l}\text { Loka- } \\
\text { lizacja }\end{array}$ & $\begin{array}{l}\text { Oznacze- } \\
\text { nie APP }\end{array}$ \\
\hline 1 & Antoniew & & $54 \mathrm{~N}$ & $\begin{array}{l}\text { prawdopodobnie ekshumowany na cmentarz } \\
\text { wojenny w Dębsku }\end{array}$ & tak & NS1 \\
\hline 2 & Borzymówka I & $581 \mathrm{R}$ & $171 \mathrm{~N}$ & $\begin{array}{l}\text { prawdopodobnie ekshumowany na cmentarz } \\
\text { wojenny Borzymówka III }\end{array}$ & nie & \\
\hline 3 & Borzymówka II & $880 \mathrm{R}$ & $182 \mathrm{~N}$ & $\begin{array}{l}\text { prawdopodobnie ekshumowany na cmentarz } \\
\text { wojenny Borzymówka III }\end{array}$ & nie & \\
\hline 4 & Borzymówka III & $3512 \mathrm{R}$ & $1037 \mathrm{~N}$ & $\begin{array}{l}\text { Cmentarz zbiorczy, pierwotnie pochowano } \\
\text { na nim: } 159 \mathrm{~N}, 818 \mathrm{R} \text { (po lewej: liczba } \\
\text { pochowanych po I fazie komasacji) }\end{array}$ & tak & NS8 \\
\hline 5 & Braki (ew. Baraki) & & $?$ & $\begin{array}{l}\text { mogiła polowa, liczba pochowanych, praw- } \\
\text { dopodobnie N, nieznana }\end{array}$ & nie & \\
\hline 6 & Brzeziny & & $1 \mathrm{~N}$ & $\begin{array}{l}\text { prawdopodobnie ekshumowany na cmentarz } \\
\text { wojenny Osmoleniec, gm. Kiernozia }\end{array}$ & nie & \\
\hline 7 & Dębsk & & $264 \mathrm{~N}$ & $\begin{array}{l}\text { pierwotnie pochowano na nim } 98 \mathrm{~N} \text { (po lewej: } \\
\text { liczba pochowanych po I fazie komasacji) }\end{array}$ & nie & \\
\hline 8 & $\begin{array}{l}\text { Gradów Marysinek- } \\
\text { Wikicinek }\end{array}$ & $553 \mathrm{R}$ & $2 \mathrm{~N}$ & nie dokładano szczątków z ekshumacji & tak & NS7 \\
\hline 9 & Kozłów Biskupi I & $562 \mathrm{R}$ & $307 \mathrm{~N}$ & $\begin{array}{l}\text { pierwotnie pochowano na nim } 279 \mathrm{R} \text { i } 123 \mathrm{~N} \\
\text { (po lewej: liczba pochowanych po I fazie } \\
\text { komasacji) }\end{array}$ & tak & NS3 \\
\hline 10 & Kozłów Biskupi II & $396 \mathrm{R}$ & $52 \mathrm{~N}$ & $\begin{array}{l}\text { pierwotnie pochowano na nim } 146 \mathrm{R} \text { i } 23 \mathrm{~N} \\
\text { (po lewej: liczba pochowanych po I fazie } \\
\text { komasacji) }\end{array}$ & nie & \\
\hline 11 & Kozłów Biskupi [III] & & $14 \mathrm{~N} ?$ & $\begin{array}{l}\text { mogiła zbiorowa lub kwatera na cmentarzu } \\
\text { parafialnym }\end{array}$ & nie & NS2 \\
\hline 12 & Kozłów Szlachecki & & $112 \mathrm{~N}$ & $\begin{array}{l}\text { prawdopodobnie ekshumowany na cmentarz } \\
\text { wojenny w Dębsku }\end{array}$ & tak & NS4 \\
\hline 13 & Kurdwanów I & $1572 \mathrm{R}$ & $131 \mathrm{~N}$ & brak danych & tak & NS10 \\
\hline 14 & Kurdwanów II & $145 \mathrm{R}$ & $27 \mathrm{~N}$ & $\begin{array}{l}\text { prawdopodobnie ekshumowany na cmentarz } \\
\text { wojenny Borzymówka III }\end{array}$ & tak & NS9 \\
\hline
\end{tabular}


cd. tab. 1

\begin{tabular}{|c|c|c|c|c|c|c|}
\hline L.p. & $\begin{array}{l}\text { Nazwa miejscowości } \\
\text { (gm. Nowa Sucha) }\end{array}$ & $\begin{array}{l}\text { Liczba } \\
\text { pocho- } \\
\text { wanych }\end{array}$ & $\begin{array}{l}\mathrm{R}-\text { armia } \\
\text { rosyjska } \\
\mathrm{N}-\text { armia } \\
\text { niemiecka }\end{array}$ & $\begin{array}{c}\text { Wtórne przekształcenia miejsc spoczynku } \\
\text { (ekshumacje, komasacje etc.) }\end{array}$ & $\begin{array}{l}\text { Loka- } \\
\text { lizacja }\end{array}$ & $\begin{array}{l}\text { Oznacze- } \\
\text { nie APP }\end{array}$ \\
\hline 15 & Mizerka [I] & $147 \mathrm{R}$ & $31 \mathrm{~N}$ & $\begin{array}{l}\text { prawdopodobnie ekshumowany na cmentarz } \\
\text { wojenny Borzymówka III }\end{array}$ & nie & \\
\hline 16 & Mizerka [II] & $138 \mathrm{R}$ & $31 \mathrm{~N}(?)$ & $\begin{array}{l}\text { prawdopodobnie ekshumowany na cmentarz } \\
\text { wojenny Borzymówka III }\end{array}$ & nie & \\
\hline 17 & Mizerka Nowa & $143 R$ & $188 \mathrm{~N}$ & $\begin{array}{l}\text { prawdopodobnie ekshumowany na cmentarz } \\
\text { wojenny Borzymówka III }\end{array}$ & nie & \\
\hline 18 & Sucha & $472 \mathrm{R}$ & $79 \mathrm{~N}$ & $\begin{array}{l}\text { prawdopodobnie ekshumowany na cmentarz } \\
\text { wojenny Borzymówka III }\end{array}$ & nie & \\
\hline 19 & Zakrzew & $283 \mathrm{R}$ & $184 \mathrm{~N}$ & $\begin{array}{l}\text { cmentarz wojenny na terenie majątku (ze- } \\
\text { społu dworsko-folwarcznego) prawdopo- } \\
\text { dobnie ekshumowany na cmentarz wojenny } \\
\text { Kozłów Biskupi I }\end{array}$ & tak/nie & NS5? \\
\hline 20 & $\begin{array}{l}\text { Żylin [I] [Stary lub } \\
\text { Nowy] }\end{array}$ & $75 \mathrm{R}$ & $88 \mathrm{~N}$ & $\begin{array}{l}\text { prawdopodobnie ekshumowany na cmentarz } \\
\text { wojenny Borzymówka III }\end{array}$ & tak/nie & NS6? \\
\hline 21 & $\begin{array}{l}\text { Żylin [II] [Stary lub } \\
\text { Nowy] }\end{array}$ & $113 \mathrm{R}$ & $81 \mathrm{~N}$ & $\begin{array}{l}\text { prawdopodobnie ekshumowany na cmentarz } \\
\text { wojenny Borzymówka III }\end{array}$ & tak/nie & NS6? \\
\hline
\end{tabular}

Opracowanie: Anna I. Zalewska (2018) na podstawie danych zebranych w ramach projektu Archeologiczne Przywracanie Pamięci o Wielkiej Wojnie (APP) przez Małgorzatę Karczewską w wyniku kwerendy archiwalnej przeprowadzonej w archiwum Volksbund Deutsche Kriegsgräberfürsorge w Kassel oraz Ministerstwa Spraw Zagranicznych w Berlinie. Jak zaznacza badaczka, przechowywane tam dokumenty nie stanowią kompletnej dokumentacji dotyczącej grobownictwa wojennego w okresie międzywojennym na terenie Polski, a jedynie odpisy korespondencji. $\mathrm{Z}$ tego powodu nie należy przyjmować, że przedstawione dane są wyczerpujące i ostateczne.

Lokalizację czterech spośród wymienionych tu cmentarzy wojennych zdołaliśmy dookreślić dzięki przedwojennym mapom topograficznym, sporządzonym przez Wojskowy Instytut Geograficzny, w połączeniu z danymi archiwalnymi. Ponadto dwa spośród cmentarzy zlokalizowane zostały wyłącznie na podstawie źródeł historycznych, dlatego ich status traktujemy jako domniemany: to Antoniew (NS1) i Zakrzew (NS5).

Do skutecznej lokalizacji cmentarzy wojennych (w tym pięciu znajdujących się na terenie gminy Nowa Sucha) przyczyniła się zastosowana w procesie archeologicznego przywracania pamięci złożona i wielofazowa korelacja różnego typu danych historycznych, archeologicznych i teledetekcyjnych w środowisku GIS (w toku badań czerpaliśmy m.in. z inspiracji zawartych w pracach: Hesse, 2010; Kokalj, Zakšek, Oštir, 2011; Opitz, 2013; Hanson, Oltean, 2013). Wyniki historycznej kartografii skorelowane ze zgeopozycjonowanymi zdjęciami lotniczymi, z danymi $\mathrm{z}$ lotniczego skanowania laserowego oraz prospekcja terenowa pozwoliły na wiążącą lokalizację tych cmentarzy wojennych, które zachowały się choćby w szczątkowej własnej formie terenowej. Wyniki tego etapu procesu poznawczego, w odniesieniu do reliktów Wielkiej Wojny nad Rawką i Bzurą, zostały zawarte w tabeli 1. 
Oznacza to, że po pozostałych cmentarzach wojennych nie zachował się żaden ślad, który zdołalibyśmy rozpoznać jako pozwalający na lokalizację cmentarza/mogiły wojennej - ani w archiwaliach, ani w zasobach kartograficznych, ani w terenie (co nie oznacza, że pod powierzchnią ziemi nie ma już żadnych reliktów nieznanych nam dotychczas cmentarzy wojennych).

Analiza przestrzenna cmentarzy wojennych zlokalizowanych m.in. na terenie gminy Nowa Sucha pozwala stwierdzić, że praktyka dotycząca wyboru miejsc, w których byli chowani polegli żołnierze, nie odbiegała zasadniczo od tego, co można zaobserwować $\mathrm{w}$ przypadku cmentarzy wojennych położonych $\mathrm{w}$ gminach sąsiednich, zwłaszcza w gminie Bolimów, gdzie zlokalizowano 34 takie miejsca, z czego zaledwie trzy były uprzednio wskazane w rejestrze zabytków województwa łódzkiego (szerzej na ten temat por. Zalewska, Cyngot, 2017).

Do naszych czasów zachowały się zarówno cmentarze o wyraźnej formie terenowej, które nie zostały poddane ekshumacji, jak i te, które na skutek procesów wtórnych uległy daleko idącym przekształceniom. We współczesnych granicach gminy Nowa Sucha, analogicznie do gmin sąsiednich, przy lokowaniu mogił wojennych korzystano z istniejących cmentarzy parafialnych, na których tworzono kwatery wojenne, np. na cmentarzach w Kozłowie Biskupim (NS2) i Kozłowie Szlacheckim (NS4).

Rozpoznane miejsca pochówków pierwotnie były w większości przypadków intencjonalnie wyróżniane $\mathrm{w}$ terenie przez otoczenie ich rowem lub nasypem ziemnym oraz przez nasadzenia roślin. W kilku przypadkach cmentarze założono przy głównych drogach i skrzyżowaniach, np. niewielki cmentarz z nasypem ziemnym w kształcie podkowy w pobliżu Gradowa (NS7) czy największy na terenie gminy Nowa Sucha cmentarz Borzymówka III (NS8), na który ekshumowano mniejsze cmentarze wojenne (patrz: ryc. 3).

Najczęściej cmentarze wojenne tworzono w pobliżu miejsc, w których toczyły się intensywne walki. Cechuje je harmonijna, relatywnie jednorodna forma i zróżnicowana wielkość. Załączone ilustracje (ryc. 4-7) dają wgląd zarówno w wyjściowe założenia, jak i w stopniowo następujący proces degradacji cmentarzy $\mathrm{z}$ okresu I wojny światowej w wyniku procesów naturo-kulturowych. Dane teledetekcyjne poddane analizie $w$ ramach APP umożliwiają postawienie hipotezy, że schemat tego procesu mógł być następujący (potwierdzają ją dane z przekazów ustnych zebrane w toku APP):

Do połowy lat 60 . XX wieku cmentarze wojenne (tu: $\mathrm{z}$ terenu gminy Nowa Sucha) były co pewien czas oczyszczane z zarastającej je roślinności. Świadczą o tym wyraźnie zdjęcia lotnicze z tego okresu. Widać to szczególnie wyraźnie w przypadku cmentarzy w Gradowie (NS7) (ryc. 4B-C), w Borzymówce (NS8), gdzie toczyły się walki najintensywniejsze w granicach dzisiejszej gminy Nowa Sucha (co szkicujemy na początku tekstu) czy w Kurdwanowie (NS9) (ryc. 5B-C). 


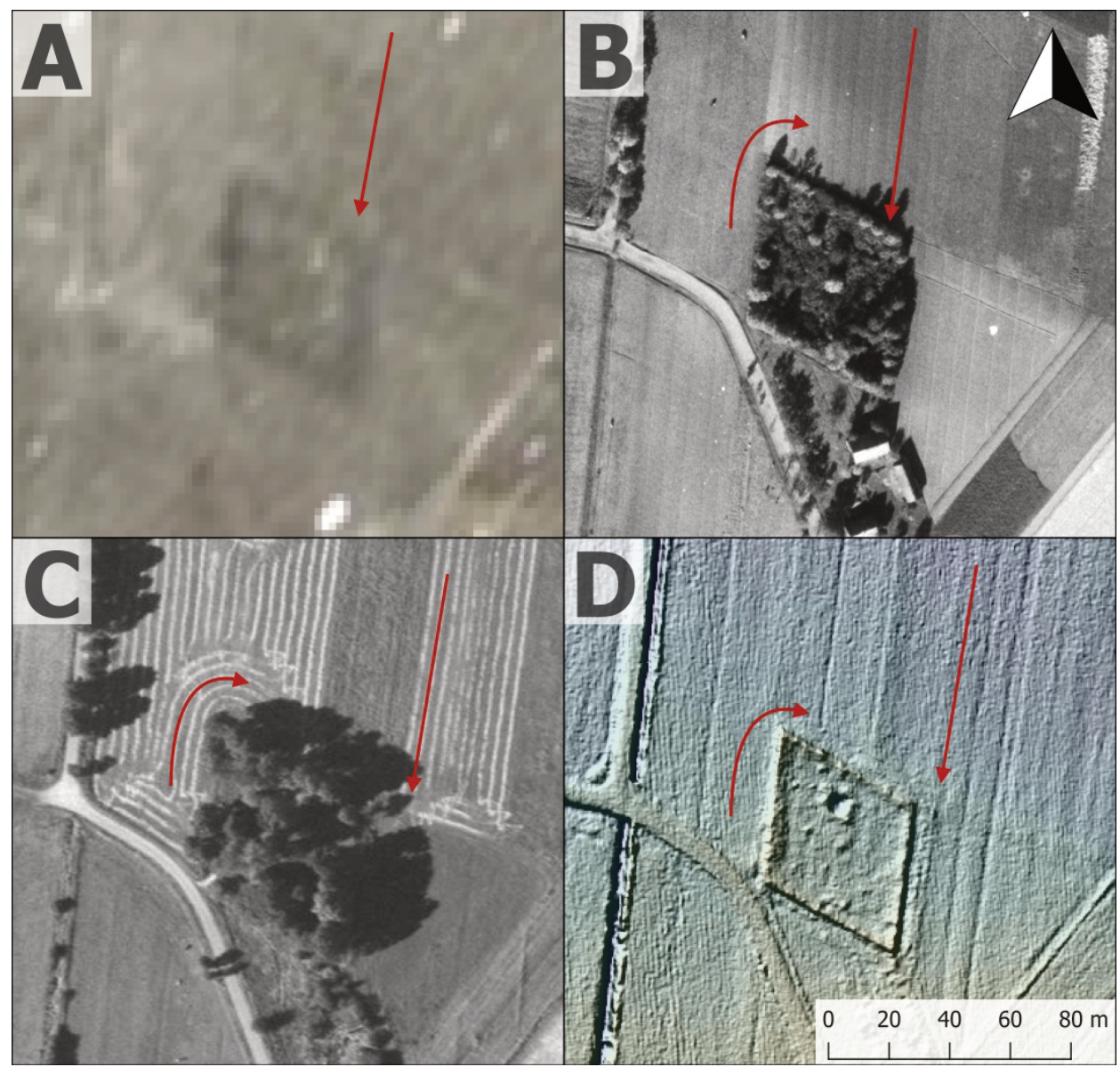

Ryc. 5. Cmentarz w Kurdwanowie (NS10), gm. Nowa Sucha: A - Fragment fotografii lotniczej wykonanej 25.05.1915; B - Zdjęcie lotnicze z 1957 r.; C - Zdjęcie lotnicze z 2004 r.; D - Pochodna numerycznego modelu terenu $z$ danych ALS (kompozycja analizy cieniowania i NMT) (Dane z bazy danych projektu APP, opracowanie G. Kiarszys).

Fig. 5. Cemetery in Kurdwanów (NS10), commune Nowa Sucha: A) - A fragment of aerial photography taken on May 25, 1915; B) - Aerial photography from 1957; C) - Aerial photography from 2004; D) - A derivative of the numerical terrain model from ALS data (composition of shading analysis and DTM) (ARM's Data Base, designed by G. Kiarszys).

Od połowy lat 70. XX wieku zaniechano czynności porządkowych i wówczas rozpoczęło się intensywne zarastanie omawianych cmentarzy - następowało przejmowanie ich przez naturę na skutek przemian/czynników kulturowych, a tym samym popadanie w niepamięć.

„Czysto ludzka sprawa”, jaką jest troska o cmentarze wojenne, spoczywająca w rękach wszystkich żyjących... przestała być postrzegana jako aksjomat. Najbar- 
dziej radykalny tego przebieg można zaobserwować w odniesieniu do cmentarza wojennego w Kozłowie Biskupim, który w świetle przekazów ustnych jeszcze na przełomie lat 70. i 80. funkcjonował jako napowierzchniowo czytelny, a później został brutalnie zaorany w procesie „gospodarki leśnej”, co poskutkowało niemal całkowitym zatarciem jego cech, aktualnie bardzo subtelnie, w sposób minimalny widocznych na powierzchni ziemi (ryc. 6).

$\mathrm{W}$ odniesieniu do tego cmentarza potwierdziła się teza, że w procesie badania obszarów trudno dostępnych (tu: porośniętych gęstą roślinnością i silnie przekształconych, na których tradycyjne archeologiczne metody prospekcji terenowej byłyby mniej efektywne; za: Risbøl, 2013; Kiarszys, Szalast, 2014), sprawdza się stosowanie analiz pochodnych Lotniczego Skanowania Laserowego (ang. Airborne Laser Scanning, dalej ALS) (Crutchley, Crow, 2009; Challis, Howard, 2013). Metoda ALS została wykorzystana m.in. w dokumentowaniu szczegółowej topografii terenu dla bardzo silnie przekształconej własnej formy terenowej stanowiska APP-27, tj. cmentarza oznaczonego jako NS2 w Lesie Kozłowskim. Z uwagi na przeprowadzenie sztucznego zalesienia na obszarze tego cmentarza wojennego, dokonanego prawdopodobnie na przełomie lat 80 . i $90 .^{5}$, nie było innej możliwości zarejestrowania reliktów jego formy terenowej (Devereux i in., 2005; Cowley, Opitz, 2013).

Warto tu odnotować, że praca $\mathrm{z}$ danymi $\mathrm{z}$ lotniczego skanowania laserowego związana jest z podejmowaniem arbitralnych decyzji, które mają wpływ na uzyskiwany efekt końcowy (np. Kiarszys, Banaszek, 2017). Wiedza na temat zasad działania lotniczego skanowania laserowego, specyfiki wykorzystanych źródeł, ich jakości, terminu skanowania, metod przetwarzania i wykorzystanych w analizach typów wizualizacji ma duże znaczenie na każdym $\mathrm{z}$ etapów rejestrowania (mapowania) obiektów archeologicznych i ich interpretacji.

Metoda ta okazała się pomocna w odniesieniu do 6 z 21 analizowanych przypadków stanowiących relikty cmentarzy na terenie gminy Nowa Sucha. Numeryczny Model Terenu (dalej NMT) i jego pochodne wykonane na potrzeby APP były interpretowane $\mathrm{w}$ bazie danych GIS-APP. Umożliwiły one zarówno analizę porównawczą reliktów poszczególnych cmentarzy wojennych na obszarze objętym badaniami, jak i określenie ich relacji przestrzennych względem fortyfikacji polowych, których część pozostaje czytelnym elementem krajobrazu. Ich relikty zachowały się zwłaszcza na terenie Puszczy Bolimowskiej (gmina Bolimów), w obrębie której zdelimitowana została przestrzeń o potencjale Parku Kulturowego, a nawet Pomnika Historii, m.in. dzięki metodom teledetekcyjnym (szerzej na ten temat Zalewska, Czarnecki, Jakubczak, 2015).

\footnotetext{
${ }^{5}$ Informacja ta pochodzi z rozmów przeprowadzonych w trakcie prowadzenia badań archeologicznych na stanowisku APP-27 w Kozłowie Biskupim z mieszkańcami Ziemiar, Kozłowa i Skierniewic przez A. I. Zalewską. Rozmowy te były stałym i istotnym elementem tropienia tych elementów materialnych pozostałości Wielkiej Wojny, których nieliczni mieszkańcy są niezmiennie świadomi.
} 


\begin{tabular}{|c|c|c|c|c|}
\hline 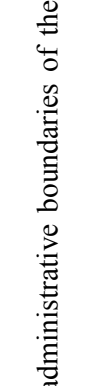 & 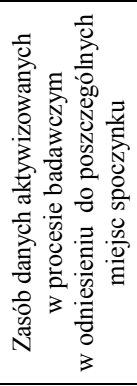 & 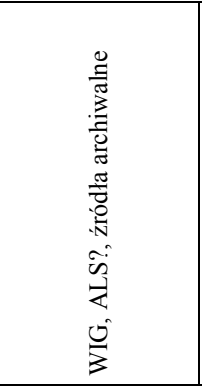 & 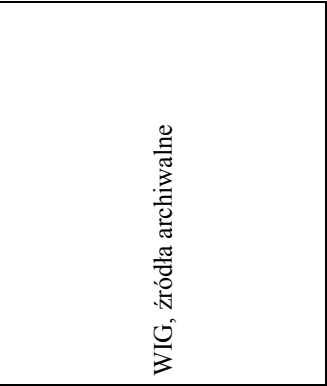 & 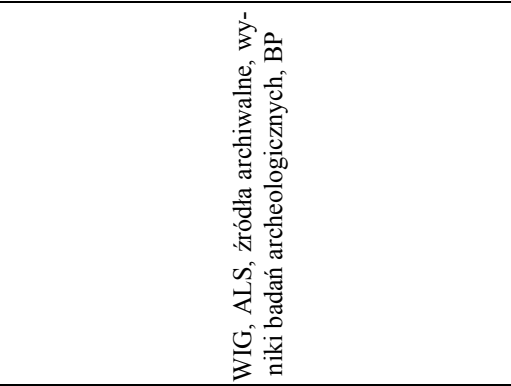 \\
\hline 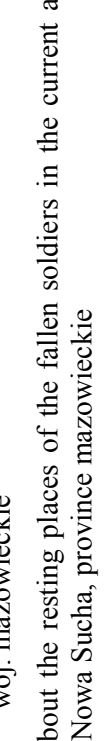 & 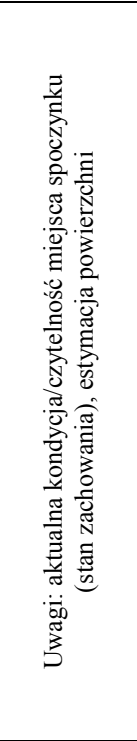 & 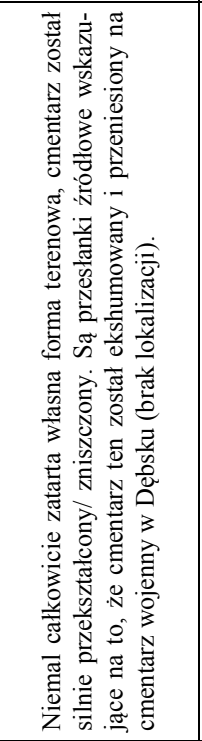 & 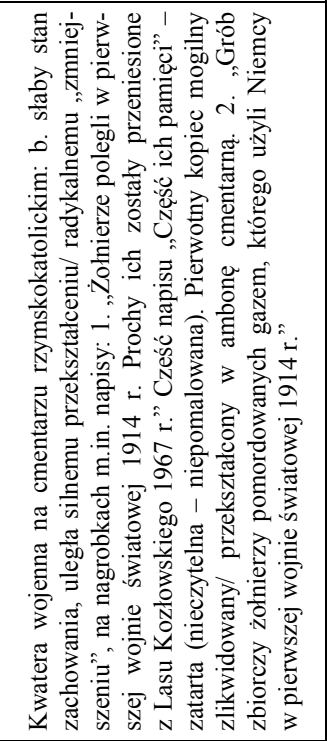 & 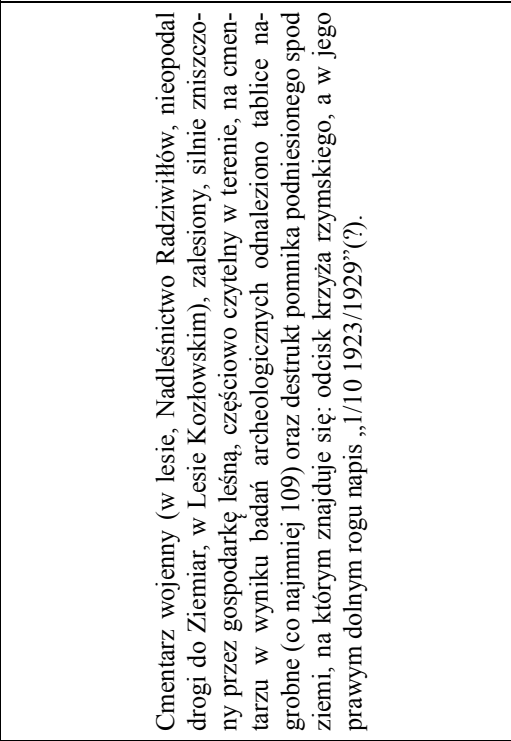 \\
\hline 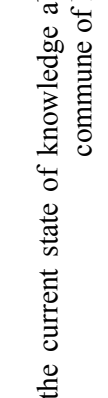 & 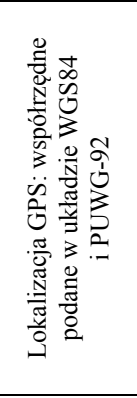 & 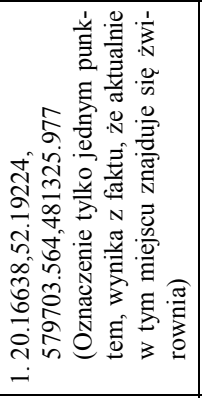 & 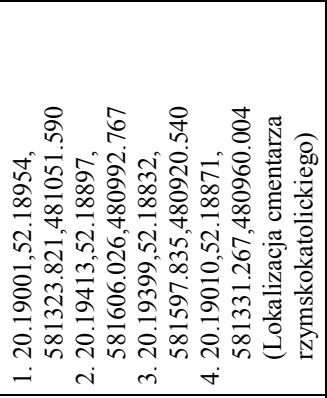 & 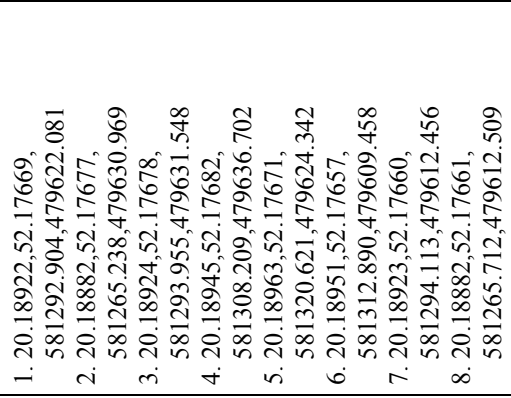 \\
\hline 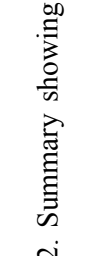 & 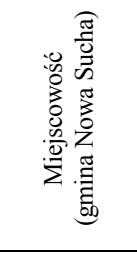 & 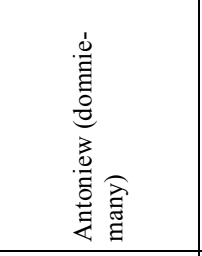 & 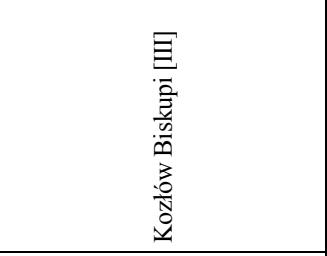 & 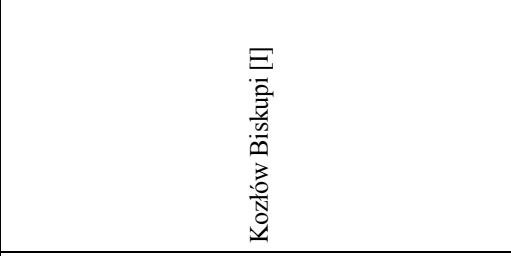 \\
\hline$\frac{0}{\frac{\pi}{\sigma}}$ & 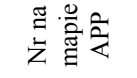 & Z & z & Z \\
\hline
\end{tabular}




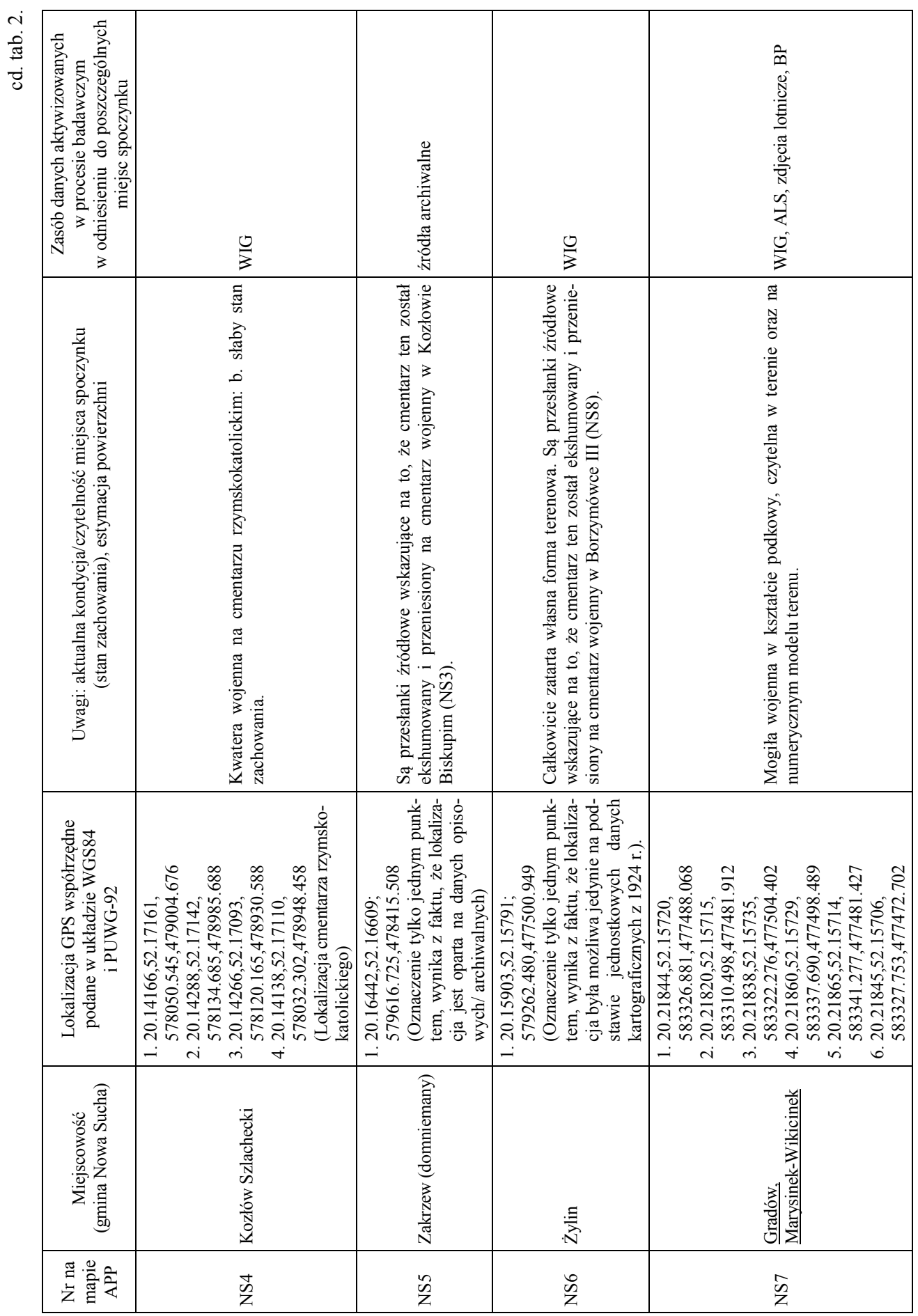




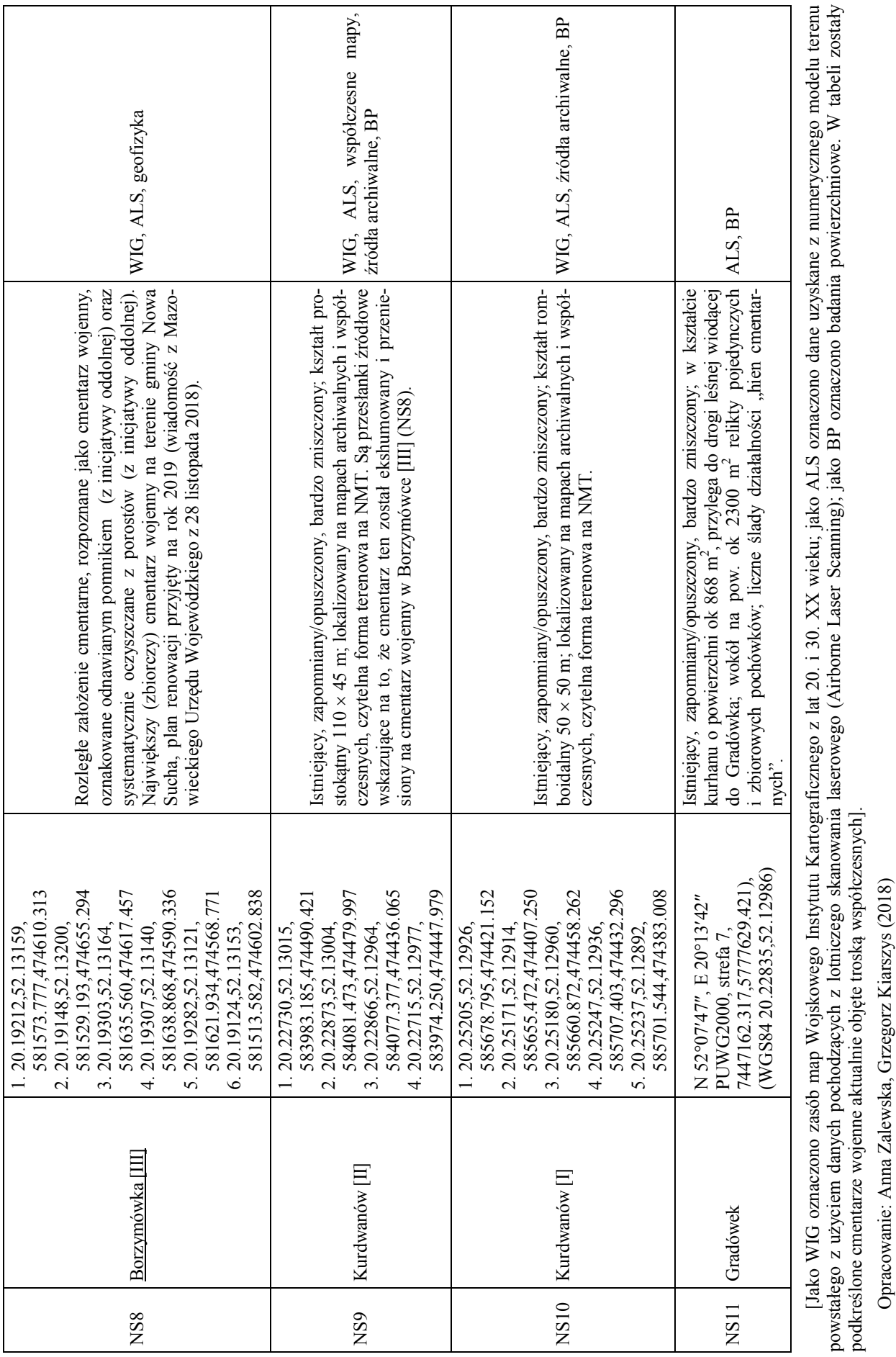


Część spośród analizowanych przez korelacje różnego typu danych cmentarzy wojennych wciąż jednak pozostaje problematyczna pod względem ich pewnej lokalizacji. Dotyczy to m.in. cmentarza wojennego we wsi Antoniew (NS1): cmentarz rozpoznany został wyłącznie na podstawie mapy z 1924 r. Jednocześnie odnotowano brak oznaczenia tego cmentarza na późniejszych mapach WIG, co może wynikać z faktu jego ekshumowania na cmentarz wojenny w Dębsku, który w 1926 r. został określony jako cmentarz ,zbiorczy” w złym stanie zachowania: ogrodzenie nie istniało, nasypy mogił były rozmyte i zapadnięte (Deutsche Gesandtschaft Warschau). Aktualny brak reliktów cmentarzy w Antoniewie i Dębsku na modelu NMT wynika z silnego przekształcenia terenu, co skutkuje brakiem czytelnej na powierzchni formy reliktowej.

Równie problematyczna pozostaje lokalizacja cmentarza wojennego we wsi Zakrzew (NS5). Został on ramowo zlokalizowany dzięki mapie z lat 20. „w obrębie parku” i/lub ,na tyłach gospodarstwa” (mimo braku oznaczenia cmentarza na mapie) $)^{6}$. Z zapisu archiwalnego, który może być korelowany z tym cmentarzem wojennym, wynika, że spoczywało na nim 184 żołnierzy armii niemieckiej i 283 żołnierzy armii rosyjskiej i że był on ekshumowany na cmentarz wojenny Kozłów Biskupi [I] (NS3). Na pochodnych numerycznego modelu terenu nie jest możliwe rozpoznanie przestrzeni reliktów cmentarza, ponieważ jest tam płaskie pole uprawne.

Problematyczna jest również lokalizacja cmentarza wojennego we wsi Żylin (NS6). W miejscowości tej z udziałem źródeł archiwalnych rozpoznane zostały dwa cmentarze wojenne: Żylin I i Żylin II. Na podstawie mapy z lat 20. jeden z dwóch cmentarzy w Żylinie oznaczony został na mapie w skali 1:100 000 (A40 B30 〈XXIII 7〉 ŁOWICZ 1924) z 1924 r. Aktualnie brak jest napowierzchniowych cech (własnych form terenowych) możliwych do rozpoznania na pochodnych NMT jako przestrzeń reliktowa cmentarza. Z opisu, który może być korelowany z tym cmentarzem, poświadczającego, że spoczywało tam 88 żołnierzy armii niemieckiej i 75 żołnierzy armii rosyjskiej, wynika, że mógł on być ekshumowany na cmentarz zbiorczy Borzymówka [III]. Analiza ALS nie przyniosła wiążącej odpowiedzi - na analizowanym terenie są pola, miejsca tego nie chronią żadne rośliny wysokie; można więc przyjąć, że po przeniesieniu szczątków miejsce po cmentarzu zostało całkowicie zniwelowane.

Zarówno pochodne lotniczego skanowania laserowego, jak i historyczne fotografie lotnicze okazały się natomiast kluczowym potwierdzeniem uwierzytelniającym precyzyjną lokalizację cmentarzy wojennych we współczesnym krajobrazie w odniesieniu do pięciu spośród 21 odnotowywanych dla prezentowanego tu obszaru. Dzięki wykorzystaniu danych ALS, precyzyjnie rozpoznano stan napowierzchniowego zachowania (kondycji materialnej) m.in. cmentarzy wojennych we wsiach:

\footnotetext{
${ }^{6}$ Niestety na żadnej znanej nam mapie nie ma oznaczonej lokalizacji cmentarza z Zakrzewa. Najbliższy jest w Kozłowie-Biskupim (NS3). Rodzi się pytanie, czy zaistnienie cmentarza wojennego w Zakrzewie nie jest rezultatem pomyłki nazewniczej?/nieporządku w rejestrach i czy ten sam cmentarz nie został raz opisany jako Kozłów Biskupi, a innym razem jako Zakrzew.
} 


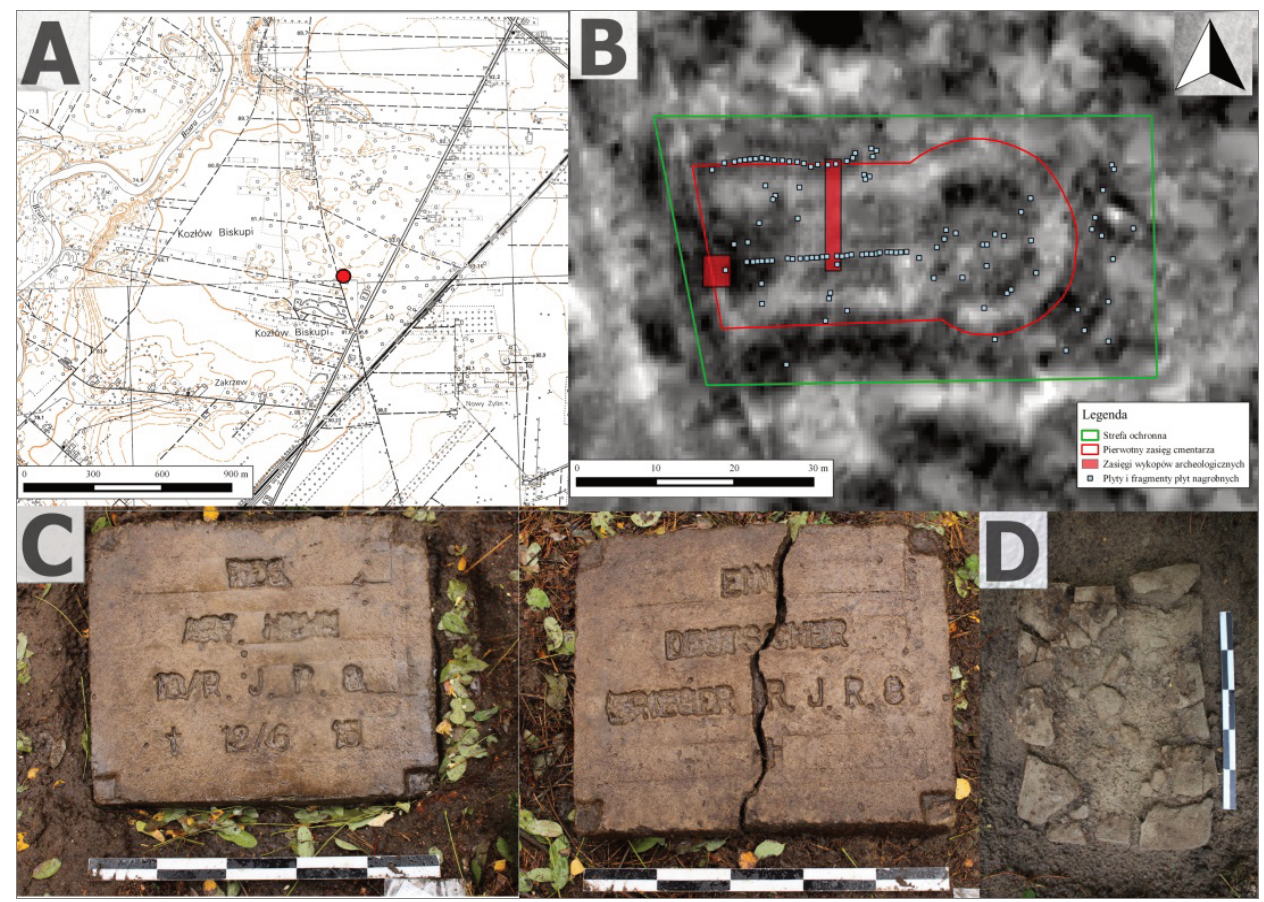

Ryc. 6. Cmentarz w Kozłowie Biskupim (NS3), gm. Nowa Sucha: A - Lokalizacja cmentarza na mapie topograficznej; B - Schematyczna prezentacja wyników badań APP na podstawie danych teledetekcyjnych i badań archeologicznych: czerwoną linią oznaczono zdelimitowany zakres cmentarza, zieloną linią oznaczono zakres rekomendowany do ścisłej ochrony, niebieskimi punktami oznaczono tablice nagrobne odnalezione przez archeologów; C-D - Tablice nagrobne w różnym stanie zachowania (Dane z bazy danych projektu APP, opracowanie A. I. Zalewska).

Fig. 6. Cemetery in Kozłów Biskupi (NS3), commune Nowa Sucha: A - The location of the cemetery on the topographic map; B - Schematic presentation of the results of ARM research based on remote sensing data and archaeological research: the red line indicates the demarcated range of the cemetery, the green line marked the recommended range for strict protection, the blue points indicate the localized grave plates located by archaeologists; C-D - Grave plates in a different state of preservation (ARM's Data Base, designed by A. I. Zalewska).

- Kurdwanów [II] (NS9), który został dookreślony jako słabo zachowane prostokątne założenie o wymiarach $110 \times 45 \mathrm{~m}$, trwające $\mathrm{w}$ czasie i chronione przez rośliny. Status tego cmentarza jest nieoczywisty, ponieważ w świetle danych archiwalnych prawdopodobnie ekshumowano stąd 27 żołnierzy armii niemieckiej i 145 żołnierzy armii rosyjskiej na cmentarz zbiorczy we wsi Borzymówka [III] (NS8);

- Kurdwanów [I] (NS10), który, najpierw zlokalizowany kartograficznie, został precyzyjnie dookreślony jako czytelna na pochodnych NMT własna forma terenowa o kształcie romboidalnym i wymiarach $50 \times 50 \mathrm{~m}$, a następnie zweryfikowany w terenie. Cmentarz ten jest nieustannie trwającym w czasie mate- 
rialnym nośnikiem pamięci o Wielkiej Wojnie, chronionym przez rośliny, z czynnym udziałem decyzji ludzi, tj. kilku generacji rolników, którzy decydowali o omijaniu tego miejsca, uprawiając sąsiadujące $\mathrm{z}$ cmentarzem pola (por. ryc. 5C, D, gdzie czerwone strzałki określają kierunki oszczędzającej relikt orki). Były to decyzje godne szacunku, zwłaszcza że stanowiły raczej głos sumienia niż efekt odgórnego nakazu (ponieważ cmentarz ten nie jest formalnie chroniony jako cmentarz „rejestrowy”). Zasadność tej decyzji wzmacnia m.in. zapis archiwalny, który może być korelowany z tym cmentarzem. Pozwala on zakładać, że niezmiennie spoczywają na nim szczątki co najmniej 131 poległych żołnierzy armii niemieckiej oraz 1572 poległych żołnierzy armii rosyjskiej (Projekt einer weitgehenden Zusammenlegung...).

Jednak nie wszystkie cmentarze wojenne z terenu gminy Nowa Sucha otoczone były akceptacją.

\section{CMENTARZ WOJENNY W KOZLOWIE BISKUPIM}

Do zlokalizowania cmentarza wojennego we wsi Kozłów Biskupi, położonego na działce nr 278 w miejscowości Kozłów Biskupi, gmina Nowa Sucha, powiat Sochaczew, województwo mazowieckie, którego właścicielem jest Nadleśnictwo Radziwiłłów, przyczyniły się:

1) analizy zasobów kartograficznych;

2) analizy pochodnych ALS wygenerowanych w toku projektu APP;

3) rozmowy z mieszkańcami Kozłowa i okolic;

4) prospekcja terenowa, w wyniku której zostało odnalezionych kilka płyt nagrobnych oraz relikt pomnika częściowo wystający spod ziemi, których fragmenty zlokalizowano $\mathrm{w}$ trakcie badań powierzchniowych przeprowadzonych w ramach projektu APP;

5) badania inwazyjne $z$ wykorzystaniem metody szpilowania w obrębie zdelimitowanej na podstawie wizualizacji NMT strefy cmentarza oraz w jego bliskim kontekście. W wyniku zastosowania szpilowania rozpoznane zostały zalegające pod ziemią (w warstwie przypowierzchniowej) pozostałe relikty pomnika i płyty nagrobne w różnym stanie zachowania i rozdrobnienia;

6) badania sondażowe.

W efekcie badań archeologicznych znalezionych zostało 109 płyt nagrobnych w różnym stanie zachowania.

Każda z płyt została oczyszczona ze ściółki leśnej oraz zadokumentowana fotograficznie, a każdy z rogów płyty domierzono tachimetrem laserowym (patrz: ryc. 6B). Układ tablic jedynie częściowo wpisywał się w system organizacji przestrzennej potencjalnego cmentarza widocznego na NMT, przyjęty za pierwotny (ryc. 6B). W części wschodniej znaczna część tablic została przemieszczona oraz zniszczona 


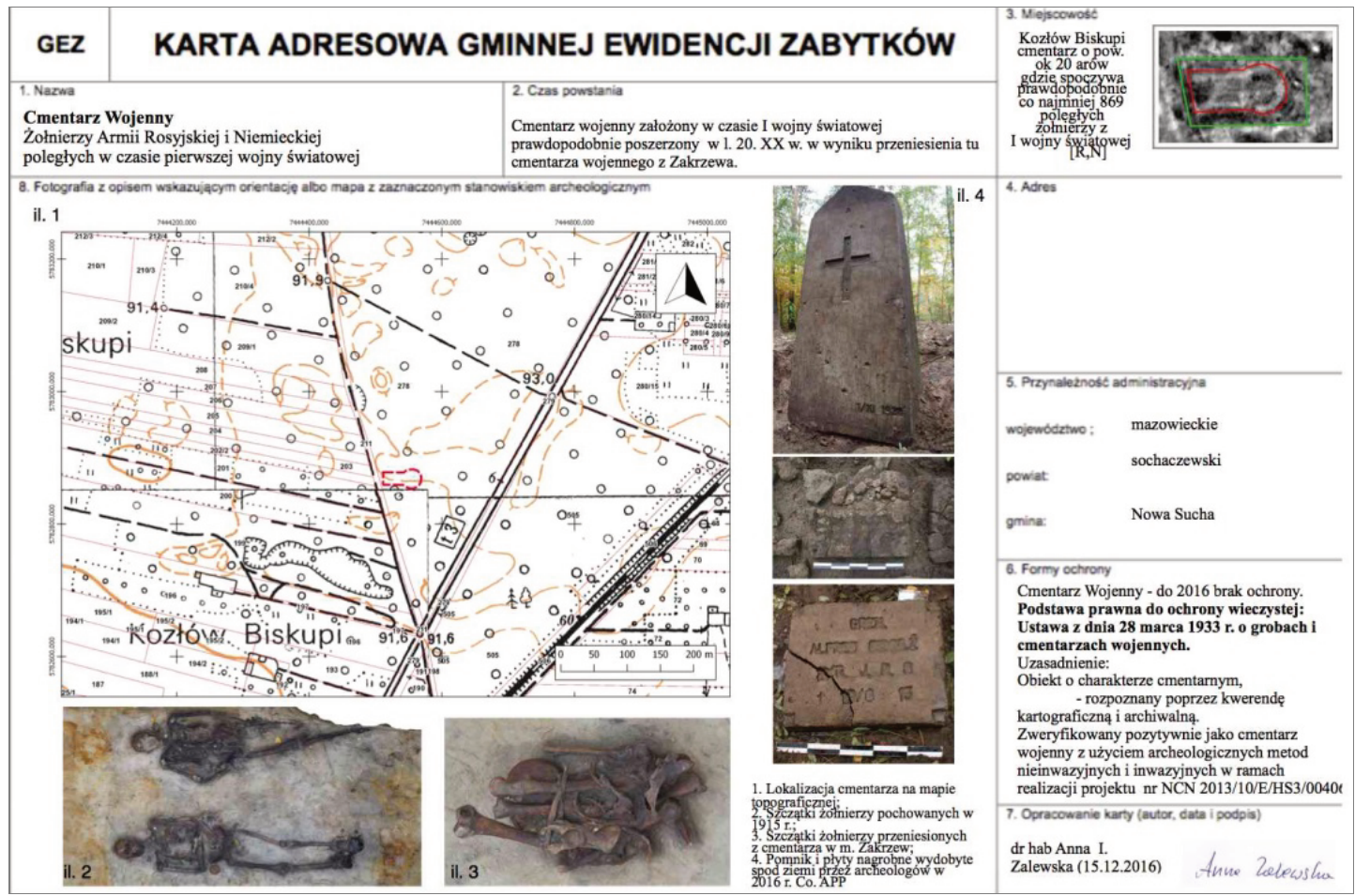

Ryc. 7. Karta Gminnej Ewidencji Zabytków wytworzona w wyniku badań archeologicznych w ramach projektu Archeologiczne Przywracanie Pamięci o Wielkiej Wojnie (APP) przekazana stosownym urzędom wraz z załącznikami i uzasadnieniem objęcia ochroną zniszczonego cmentarza wojennego w Kozłowie Biskupim (stanowisko APP-27) (opracowanie A. I. Zalewska).

Fig. 7. The card of the Municipal Monument Records created as a result of archaeological research within the project Archaeological Restoration of the Great War (ARM), transferred to the appropriate authorities along with attachments and justification for the protection of the destroyed war cemetery in Kozłów Biskupi (site APP-27) (prepared by A. I. Zalewska).

przez orkę leśną, zaś tablice po stronie zachodniej zinterpretowano jako prawdopodobnie wtórnie przeniesione oraz ponownie ułożone w dwóch nieregularnych liniach. W trakcie prac został też sondażowo rozpoznany kontekst pomnika. Pomnik wykonany jest z cementu lepszej jakości niż płyty nagrobne, w przypadku których erozja okazała się daleko posunięta (ryc. 6D). Na środku podniesionego spod ziemi pomnika znajduje się odcisk krzyża łacińskiego, a w jego prawym dolnym rogu napis ,1/10 1923/1929"(?) (ryc. 7, il. 4).

Badania nieinwazyjne, powierzchniowe oraz szpilowanie nie przyniosły odpowiedzi na pytanie, czy jest to obiekt pozostający w pełni cmentarzem, czy obszar poekshumacyjny. Również informacje ustne od starszych mieszkańców tej miejscowości były sprzeczne. Tymczasem w zastanej rzeczywistości warunkiem formalnego przywrócenia miejscu jego cmentarnego charakteru było dowiedzenie obecności 
szczątków poległych żołnierzy w jego obrębie. $\mathrm{Z}$ wyżej wymienionych powodów wykonano dwa ograniczone do niezbędnego minimum sondaże, czego wynikiem było odsłonięcie szczątków poległych żołnierzy. Żadne szczątki nie zostały podjęte podczas prowadzenia tych badań. Opis antropologiczny został wykonany in situ przez dr. Łukasza Maurycego Stanaszka.

Wyniki sondażowych badań archeologicznych na stanowisku APP-27 dały definitywną odpowiedź, że cmentarz w Kozłowie Biskupim pozostaje niewyekshumowanym cmentarzem wojennym, na którym spoczywają polegli w układzie anatomicznym. Dodatkowo stwierdzono, z użyciem inwazyjnych metod archeologicznych, że na cmentarzu tym złożone zostały także szczątki poległych z innych cmentarzy wojennych (por. ryc. 7, il. 3).

Archeologia przyczyniła się w tym wypadku do rozpoznania niektórych personaliów i przynależności pułkowej kilku spośród spoczywających na cmentarzu żołnierzy, dzięki interpretacji napisów na płytach nagrobnych. Płyty te pozostają aktualnie in situ, $\mathrm{tj}$. w miejscu odnalezienia, i z uwagi na ich bardzo słaby stan zachowania wymagają pilnego zabezpieczenia oraz trwałej opieki i ochrony konserwatorskiej. Wniosek taki został przekazany wraz z uzasadnieniem do Mazowieckiego Urzędu Wojewódzkiego oraz Urzędu Gminy Nowa Sucha w grudniu 2016 r. Archeolodzy wykonali także dokumentację stanowiącą podstawę do otoczenia tego cmentarza formalną opieką, tj. Kartę Gminnej Ewidencji Zabytków (ryc. 7) oraz Kartę Ewidencyjną Miejsc Pamięci Narodowej. O wynikach badań powiadomiony też został właściciel terenu - Nadleśnictwo Radziwiłłów. Zakładamy, że wyniki badań archeologicznych zostaną spożytkowane jako mogące przyczynić się do objęcia pamięcią i troską miejsca spoczynku poległych żołnierzy oraz do upowszechnienia przekonania, że to „czysto ludzka sprawa”.

\section{WNIOSKI}

O materialnej kondycji cmentarzy i mogił wojennych z okresu pierwszej wojny światowej przesądzał i wciąż przesądza stosunek do nich miejscowej ludności, lokalnych i centralnych władz oraz wszelkich podmiotów odpowiedzialnych za sprawowanie nad nimi opieki. Jednocześnie jednak bardzo istotnym elementem w procesie trwania tych cmentarzy w czasie okazują się czynniki naturalne, takie jak np. roślinność chroniąca te cmentarze i towarzysząca ich naturalnemu zanikowi. Na przedstawionych powyżej przykładach pokazaliśmy, jak nierozerwalne są zależności naturo-kulturowe. Na podstawie analizy zdjęć lotniczych i pochodnych ALS można wykazać, że wyraźnie czytelna (nierozerwalna) jest relacja między trwaniem napowierzchniowych reliktów cmentarzy wojennych a roślinnością je porastającą. Analizując numeryczne modele pokrycia terenu, czy jak w tu zobrazowanych przypadkach zdjęcia lotnicze z różnych faz trwania cmentarzy, możemy dostrzec, że rośliny (drzewa) stały się strażnikami tego typu miejsc. Ten naturo-kulturowy charakter 
transformacji przejawia się również przez te sytuacje, w których próby ingerencji w środowisko naturalne (jak np. w przypadku polany w Lesie Kozłowskim i nasadzonych tam relatywnie niedawno dębów) niszczą, ale jednocześnie unaoczniają elementy architektury cmentarnej, które - choć już w bardzo słabej kondycji - wciąż mogą się okazać sprawcze. Tak właśnie kozłowskie płyty nagrobne i relikt pomnika cmentarnego przyczyniły się do wychynięcia z (nie)bytu społecznego cmentarza wojennego, którego nie zdołało uchronić pierwotne pokrycie terenu właściwe temu miejscu w czasie wojny 1914-1918 i jeszcze długo po niej (patrz: opis stanowiska APP-27, powyżej).

Na terenie analizowanego tu obszaru gminy Nowa Sucha przez archeologiczne przywracanie pamięci o Wielkiej Wojnie jako archeolodzy mogliśmy jedynie zainicjować proces lokalizowania i „odpominania” cmentarzy wojennych, dowodząc przy tym, że zarówno człowiek, jak i przyroda mogą te cmentarze zarówno chronić, jak i niszczyć. W procesie poznawczym wykazaliśmy, że większość cmentarzy z terenu tej gminy występuje w źródłach archiwalnych jedynie z nazwy lub jako „nieme” punkty na mapach archiwalnych i to doraźnie oraz selektywnie (co zobrazowaliśmy na przykładzie cmentarza wojennego usytuowanego we wsi Kozłów Biskupi).

Proces przywracania pamięci o cmentarzach wojennych na obszarach, na których nie funkcjonowały one w ostatnich dekadach jako miejsca godne/wymagające troski, zobrazowaliśmy przez wgląd w wyniki badań na stanowisku APP-27, gdzie z udziałem metod nieinwazyjnych i inwazyjnych dowiedliśmy bezsprzecznej obecności cmentarza wojennego. Szczątki poległych żołnierzy, rozpoznane w toku badań archeologicznych na tym stanowisku, celowo nie zostały przez nas przemieszczone (wyekshumowane). Obecne miejsce spoczynku szczątków poległych z Lasu Kozłowskiego oraz wszystkich przynależnych im rzeczy jest tożsame z miejscem ich odnalezienia w toku badań archeologicznych. Jest tak, ponieważ w świetle danych zebranych podczas badań APP miejsce to pozostaje niezmiennie Cmentarzem Wojennym - mimo braku zapisu w ewidencji grobów i cmentarzy wojennych województwa mazowieckiego do grudnia 2016 r. (patrz: ryc. 7). Gdyby cmentarz ten znajdował się w ewidencji grobów wojennych, nie byłby przedmiotem badań inwazyjnych w ramach projektu APP - ponieważ wiodące założenia procesu archeologicznego przywracania pamięci dotyczyły tego, aby nie „rozkopywać” cmentarzy wojennych oraz nie ekshumować cmentarzy wojennych, lecz odnajdywać takie miejsca, które są niszczone, mimo że ze względu na obecność szczątków żołnierzy faktycznie pozostają cmentarzami wojennymi, choć formalnie „nimi nie są”, tzn. nie są aktualnie uważane za cmentarze wojenne i nie są traktowane jak cmentarze czy mogiły wojenne, przez co są całkowicie pozbawione opieki i troski. W efekcie tego są one często silnie przekształcane w wyniku procesów podepozycyjnych (zarówno antropogenicznych, jak i naturalnych) czy wręcz intencjonalnie niszczone - jak to 
się stało w przypadku cmentarza w Kozłowie Biskupim na przełomie lat 80. i 90. Stają się tym samym unaocznieniem tezy, że są wypadki, gdy całkowicie nie radzimy sobie z czysto ludzką sprawą, jaką jest ,ochrona zmarłych i ich praw do nienaruszalności miejsc spoczynku, uznawana za ogólnoludzkie i ponadczasowe uniwersum”, która powinna "stać ponad partykularnymi i doraźnymi interesami” (za: Domańska, 2017, s. 55).

Badania w Kozłowie Biskupim na stanowisku określanym w toku projektu jako APP-27 potwierdzily bezdyskusyjnie cmentarny charakter tego miejsca jako cmentarza wojennego. Na do niedawna niemal calkowicie zapomnianym i zniszczonym cmentarzu wojennym w Kozlowie Biskupim spoczywa prawdopodobnie co najmniej 869 poleglych obydwu armii (Zalewska, Kiarszys, 2019; Karczewska, 2019). Zebrane i skorelowane dane pochodzące $\mathrm{z}$ analizy archiwaliów, danych z lotniczego skanowania laserowego, archiwalnych źródeł kartograficznych, współczesnych i archiwalnych zdjęć lotniczych, badań geofizycznych (zastosowanych w odniesieniu do cmentarza w Borzymówce 〈NS8〉) oraz wyników badań powierzchniowych i sondażowych (zastosowanych w odniesieniu do cmentarza w Kozłowie Biskupim «NS3〉) pozwoliły na dostarczenie stosownym podmiotom odpowiedzialnym za troskę o cmentarze wojenne na terenie Polski potencjalnie sprawczych społecznie, merytorycznych argumentów przemawiających za otoczeniem tych zlokalizowanych cmentarzy należną im opieką (szerzej na ten temat patrz: Zalewska 2017, 2019b).

Konkludując, jesteśmy przekonani, że ochrona cmentarzy i mogił wojennych również wszystkich tych aktualnie pozbawionych troski i szacunku - winna być traktowana jako tyleż czysto ludzka, co oczywista sprawa przez współczesnych nam. Cmentarze wojenne, jako trwałe $\mathrm{w}$ czasie byty formalnie poddane ponadczasowej ochronie, są podmiotami/powodami licznych procesów, mechanizmów, praktyk społecznych, stanowią istotne elementy mikrobiografii miejsc, choć w wielu przypadkach (jak w omawianych powyżej 21 przypadkach cmentarzy wojennych na terenie gminy Nowa Sucha), nie uznano ich za część takich biografii. Na przykładzie obszaru jednej z czterech gmin (gm. Nowa Sucha) badanych w ramach archeologicznego przywracania pamięci staraliśmy się wykazać, że cmentarze wojenne, jako kluczowe elementy krajobrazu pamięci i jako będące w ciągłej przemianie elementy krajobrazu przyrodniczo-kulturowego, zawierają ponadczasowy i ponadnarodowy potencjał materialnych przestróg i pobudek do refleksji (Zalewska, 2013, 2014, 2017).

\section{Podziękowania}

Dziękujemy wszystkim Członkom Zespołu powołanego do realizacji projektu APP, a w szczególności Szymonowi Domagale za wykonanie planigrafii cmentarza wojennego w Kozłowie Biskupim; Małgorzacie Karczewskiej za przeprowadzenie kwerend odnoszących się do problematyki grobownictwa wojennego; Łukaszowi 
M. Stanaszkowi za wykonanie analizy antropologicznej na stanowisku APP-27 oraz wszystkim tym, którzy przyczynili się do zebrania informacji pomocnych w opracowaniu zagadnień prezentowanych w niniejszym artykule, w tym Güntherowi Karlowi Fuchsowi, Łukaszowi Konopackiemu, Tomaszowi Kuranowi i Albertowi Wolniewskiemu za pomoc $\mathrm{w}$ rozczytywaniu napisów na płytach nagrobnych oraz tropieniu losów i biogramów spoczywających tam poległych; Konradowi Grzybowskiemu, nadleśniczemu Nadleśnictwa Radziwiłłów, za decyzję, że w obrębie cmentarza w Kozłowie Biskupim nie będzie już prowadzona intensywna gospodarka leśna, w tym nasadzenia; Janowi Szczurkowi, leśniczemu Leśnictwa Zakrzew, za czynny udział w przywracaniu cmentarza w Kozłowie pamięci; Pawłowi Rozdżestwieńskiemu za informacje na temat stosunku współczesnych do cmentarzy w okolicy Sochaczewa oraz Studentom Archeologii - praktykantom z Instytutu Archeologii UMCS za zaangażowanie w trakcie praktyk studenckich.

Wnioski zawarte w tym tekście stanowią wynik realizacji projektu „Archeologiczne Przywracanie Pamięci o Wielkiej Wojnie. Materialne pozostałości życia i śmierci w okopach na froncie wschodnim oraz stan przemian krajobrazu pobitewnego w rejonie Rawki i Bzury”. Projekt ten został przyjęty do finansowania przez Narodowe Centrum Nauki na lata 2014-2018; nr projektu NCN - Sonata BIS nr 2013/10/E/HS3/00406 i jest realizowany przy Instytucie Archeologii i Etnologii PAN pod kierownictwem dr hab. Anny I. Zalewskiej.

\section{BIBLIOGRAFIA}

Bennett, J.

2010 Vibrant matter: a political ecology of things. Durham - London: Duke University Press. Challis, K., Howard, A. J.

2013 The role of lidar intensity data in interpreting environmental and cultural archaeological landscapes. W: R. S. Opitz, D. C. Cowley (red.), Interpreting archaeological topography: airborne laser scanning, 3D data and ground observation (s. 161-170). Oxford: Oxbow books.

Cowley, D. C, Opitz, R. S.

2013 Interpreting archaeological topography: lasers, 3D data, observation, visualization and applications. W: R. S. Opitz, D. C. Cowley (red.), Interpreting archaeological topography: airborne laser scanning, 3D data and ground observation (s. 1-12). Oxford: Oxbow books.

Crutchley, S., Crow, P.

2009 The light fantastic: using airborne laser scanning in archaeological survey. Swindon: English Heritage.

De-Lazari, А. [Де-Лазари, А.]

1935 Химическое оружие на фронтах мировой войны 1914-1918 2. Москва: Государственное военное издательство. 
Devereux, B. J., Amable, G. S., Crow, P., Cliff, A. D.

2005 The potential of airborne lidar for detection of archaeological features under woodland canopies. Antiquity, 79, 648-660.

Domańska, E.

2006a Historie niekonwencjonalne. Refleksja o przeszlości w nowej humanistyce. Poznań: Wydawnictwo Poznańskie.

Domańska, E.

2006b O potrzebie przeszłości. W: D. M. Tworzowska, Ł. Olędzki (red.), Komu potrzebna jest przeszłość? Poznań: Koło Naukowe Studentów Archeologii, Instytut Prahistorii UAM, Stowarzyszenie Archeologiczne „Przeszłość dla Przyszłości”.

Domańska, E.

2017 Nekros. Wprowadzenie do ontologii martwego ciała. Warszawa: Wydawnictwo Naukowe PWN.

Hanson, W. S., Oltean, I. A.

2013 A spy in the sky: the potential of historical aerial and satellite photography for archaeological research. W: W. S. Hanson, I. A. Oltean (red.), Archaeology from historical aerial and satellite archives (s. 3-10). New York - Heidelberg - Dordrecht - London: Springer Verlag.

Hauser, K.

2007 Shadow sites. Photography, archaeology, and the British landscape 1927-1955. Oxford: Oxford University Press.

Hesse, R.

2010 LiDAR-derived Local Relief Models - a new tool for archaeological prospection. Archaeological Prospection, 17(2), 67-72.

Kaliński, S.

2013 Łowicz, w poszukiwaniu miasta etapowego. Odkrywca, 3(170), 52-57.

Kaliński, S.

2015 Bolimów 1915. Warszawa: Bellona.

Karczewska, M.

2019 Cmentarze Wielkiej Wojny na terenie pola bitwy nad Rawką i Bzurą na podstawie materiałów niemieckiego ministerstwa spraw zagranicznych oraz Volksbund Deutsche Kriegsgräberfürsorge e.v. z lat 1923-1939. W: A. Zalewska (red.), Archeologiczne przywracanie pamięci o Wielkiej Wojnie w rejonie Rawki i Bzury (w druku).

Kiarszys, G., Banaszek, Ł.

2017 Dostrzec i zrozumieć. Porównanie wybranych metod wizualizacji danych ALS wykorzystywanych w archeologii. Folia Praehistorica Posnaniensia, 22, 233-270.

Kiarszys, G., Szalast, G.

2014 Archeologia w chmurze punktów. Porównanie rezultatów filtracji i klasyfikacji gruntu w projekcie ISOK z wynikami opracowanymi w oprogramowaniu LAStools i Terrasolid. Folia Praehistorica Posnaniensia, 19, 267-292.

Kobiałka, D., Kostyrko, M., Kajda, K.

2017 The Great War and its landscapes between memory and oblivion: the case of prisoners of war camps in Tuchola and Czersk, Poland. International Journal of Historical Archaeology, 21(1), 134-151.

Kokalj, Ž., Zakšek, K., Oštir, K.

2011 Application of sky-view factor for the visualization of historic landscape features in lidar-derived relief models. Antiquity, 85, 263-273. 
Kraus, K., Pfeifer, N.

2001 Advanced DTM generation from LiDAR data. International Archives of Photogrammetry, Remote Sensing and Spatial Information Sciences, 34(3), 23-30.

Ludendorff, E.

1919 My war memories, 1914-1918. London: Hutchinson [Ludendorff, E. 2014. Moje wojenne wspomnienia 1914-1918 (cz. 1). Warszawa: Tetragon].

Martinez, D.

1996 Der Gaskrieg 1914-1918: Entwicklung, Herstellung und Einsatz chemischer Kampfstoffe.

Bonn: Bernard \& Graefe Verlag.

Minta-Tworzowska, D.

2012 Przeszłość we współczesności. W: S. Tabaczyński, A. Marciniak, D. Cyngot, A. Zalewska (red.), Przeszłość społeczna. Próba konceptualizacji (s. 1089-1098). Poznań: Wydawnictwo Poznańskie.

Morgenstern, $\mathrm{O}$.

1951 Abraham Wald, 1902-1950. Econometrica, 19(4), s. 361-367.

Opitz, R. S.

2013 An overview of airborne and terrestrial laser scanning in archaeology. W: R. S. Opitz,

D. C. Cowley (red.), Interpreting archaeological topography: airborne laser scanning, $3 D$ data and ground observation (s. 13-31). Oxford: Oxbow books.

Richter, W.

1931 Das Danziger Infanterie Regiment Nr. 128. 1914-1918 I. und II. Teil. Aus Deutschlands großer Zeit. Heldentaten deutscher Regimenten. Zeulenroda: Sporn Verlag.

Risbøl, O.

2013 Cultivating the 'wilderness' - how lidar can improve archaeological landscape understanding. W: R. S. Opitz, D. C. Cowley (red.), Interpreting archaeological topography: airborne laser scanning, 3D data and ground observation (s. 51-62). Oxford: Oxbow books.

Rothe, A.

1929 Das Reserve-Infanterie-Regiment Nr. $61 \mathrm{im}$ Weltkriege. Berlin: Verlag Tradition Wilhelm Kolk.

Rozdżestwieński, P. M., Wojewoda, J.

2013 Bzura Rawka 1914-1915. Wielka Wojna na terenie powiatu sochaczewskiego. Sochaczew: Wydawnictwo ZP.

Tarczyński, W.

2015 Nie wybiła godzina wybawienia z otchłani nieszczęść... Kronika dziejów Łowicza Władysława Tarczyńskiego. Oprac. M. Wojtylak. Seria: Wielka Wojna - codzienność niecodzienności. Biblioteka pamiętników z I wojny światowej z zasobów polskich archiwów

Wolfowitz, J. państwowych (t. 4). Warszawa: Naczelna Dyrekcja Archiwów Państwowych.

1952 Abraham Wald, 1902-1950. The Annals of Mathematical Statistics, 23(1), 1-13.

Zalewska, A. I.

2003 Archaeologies of the Contemporary Past, V. Buchli, G. Lucas (red.), London - New York 2001. Archeologia Polski, 48(1-2), 252-257.

Zalewska, A. I.

2012 Archeologia jako forma kreowania, pielęgnowania i odzyskiwania pamięci. W: S. Tabaczyński, A. Marciniak, D. Cyngot, A. Zalewska (red.), Przeszłość społeczna. Próba konceptualizacji (s. 1178-1189). Poznań: Wydawnictwo Poznańskie. 
Zalewska, A. I.

2013 Roadside lessons of historicity. The roles and the meanings of the material points of references to the Great War and in shaping historical sensitivity and awareness. Sensus Historiae, 13(4), 103-119.

Zalewska, A. I.

2014 Prospołeczna, partycypacyjna i „wspólnotowa” archeologia bliskiej przeszłości jako sposób na nadawanie sensu trwaniu (ludzi i rzeczy) oraz jako antidotum na niedostatki wiedzy i trywializację przeszłości. Studia Humanistyczne, 13(2), 19-39.

Zalewska, A. I.

2016a Archeologie współczesnych konfliktów zbrojnych jako praktykowanie prospołecznej archeologii. Przykład wartości epistemologicznej i aksjologicznej. W: A. I. Zalewska (red.), Archeologia wspótczesności (s. 125-140). Warszawa: Stowarzyszenie Naukowe Archeologów Polskich.

Zalewska, A. I.

2016b The 'Gas-scape' on the Eastern Front, Poland (1914-2014): exploring the material and digital landscapes and remembering those 'twice-killed'. W: B. Stichelbaut, D. Cowley (red.), Conflict landscapes and archaeology from above (s. 147-165). Farnham, Burlington: Ashgate Publishing.

Zalewska, A. I.

2017 Archeologia czasów współczesnych i (nie)moc działania materialnych śladów Wielkiej

Wojny w Polsce (Archaeology of the contemporaneous times and the power(lessness) of physical traces of the Great War in Poland). Ochrona Zabytków, 2, 47-77.

Zalewska, A. I.

2019a Historia użycia przez armię cesarstwa niemieckiego broni masowego oddziaływania (Massenwirkung) w rejonie Rawki i Bzury w styczniu 1915 roku. W: A. Zalewska (red.), Archeologiczne przywracanie pamięci o Wielkiej Wojnie $w$ rejonie Rawki i Bzury (w druku).

Zalewska, A. I.

2019b Materialne pozostałości konfliktów i zbrodni XX w. jako prowokacje do refleksji nad naturą związków przeszłości z teraźniejszością i przyszłością. W: Materialne pozostałości konfliktów i zbrodni XX w. świetle najnowszych badań archeologicznych (w druku).

Zalewska, A. I., Cyngot, D.

2017 Problem zanikania pamięci o miejscach spoczynku żołnierzy poległych w walkach nad Rawką i Bzurą w latach 1914-1915. Acta Universitatis Lodziensis. Folia Archaeologica, 32, 119-156.

Zalewska, A. I., Cyngot, D.

2019 Aspekt śmierci i problem (nie)obecności śladów masowej śmierci - wyniki działań wojennych 1914-1915 nad Rawką i Bzurą. W: A. Zalewska (red.), Archeologiczne przywracanie pamięci o Wielkiej Wojnie w rejonie Rawki i Bzury (w druku).

Zalewska, A. I., Cyngot, D., Czarnecki, J., Kiarszys, G.

2018 Miejsca spoczynku poległych w toku Wielkiej Wojny nad Rawką i Bzurą - ich zaistnienie, trwanie i zanik... oraz poznanie i ochrona. W: M. Karczewska (red.), Cmentarze wojenne I wojny światowej po stuleciu. Stan badań i ochrony (s. 71-102). Seria: Archeologia Pamięci (t. 5). Białystok: Ośrodek Badań Europy Środkowo-Wschodniej.

Zalewska, A., Czarnecki, J.

2016 Ślady i świadectwa Wielkiej Wojny nad Rawka i Bzura. Warszawa: Fundacja Przydrożne Lekcje Historii. 
Zalewska, A., Czarnecki, J.

2019 W „bolimowskim worku”... zastój na całej linii. Historia ustanawiania linii frontu w rejonie Rawki i Bzury. W: A. Zalewska (red.), Archeologiczne przywracanie pamięci o Wielkiej Wojnie w rejonie Rawki i Bzury (w druku).

Zalewska, A. I., Czarnecki, J., Jakubczak, M.

2015 Archaeological revival of memory of the Great War. The role of LiDAR in tracing the boundaries of the WWI Rawka Battlefield Cultural Park. Archaeologia Polona, 53, $407-412$.

Zalewska, A., Kiarszys, G.

2017 Absent presence of Great War cemeteries in the Municipality of Bolimów, Central Poland. W: A. Zalewska, J. M. Scott, G. Kiarszys (red.), The materiality of troubled pasts. Archaeologies of conflicts and wars (s. 55-81). Warszawa - Szczecin: Fundacja Przydrożne Lekcje Historii.

Zalewska, A., Kiarszys, G.

2019 Lokalizacja cmentarzy wojennych z okresu I wojny światowej poprzez korelacje danych archiwalnych, kartograficznych, teledetekcyjnych i archeologicznych (2014-2018). W: A. Zalewska (red.), Archeologiczne przywracanie pamięci o Wielkiej Wojnie w rejonie Rawki i Bzury (w druku).

\section{Źródła elektroniczne}

https://www.nid.pl/pl/Informacje_ogolne/Zabytki_w_Polsce/rejestr-zabytkow/zestawienia-zabytkownieruchomych/

\section{Źródla prawne}

Ustawa 1933

1933 Ustawa z dnia 28 marca 1933 r. o grobach i cmentarzach wojennych, Dz.U. 1933 Nr 39, poz. 311 (http://prawo.sejm.gov.pl/isap.nsf/DocDetails.xsp?id=wdu19330390311

\section{Archiwalia}

AGBol - Archiwum Państwowe w Warszawie, Oddział w Łowiczu, Akta Gminy Bolimów, nr 58, k. 7, 7v.

Deutsche Gesandtschaft Warschau - Deutsche Gesandtschaft Warschau an das Auswärtige Amt. Anlage, S. 169, Berlin, 5. Mai 1927, PA, Berlin, sygn. 47996, strony niepaginowane.

Der Direktor des Zentralnachweisamts - Der Direktor des Zentralnachweisamts für Kriegerverluste und Kriegergräber an das Auswärtige Amt, Berlin, 16. September 1937, PA AA 14013, strony niepaginowane.

Kriegstagebuch - Kriegstagebuch der 9. Armee. Zeit 05/01/-23/04/1915 (Abschrift) [maszynopis].

Kuzniecow - Kuzniecow, А. [Кузнецов, А.] [1915] Фронтовой дневник рядового Андрея Кузнецова с 1914 по 1915 (maszynopis dostępny w archiwum projektu APP, brak paginacji. Tłumaczenie fragmentów wybranych przez A. Zalewską autorstwa A. Czapiuk).

Projekt einer weitgehenden Zusammenlegung - Projekt einer weitgehenden Zusammenlegung der deutschen Kriegergräber in der Wojewodschaft Warschau. VIII. Kreis Sochaczew, PA AA Berlin, sygn. 48011, strony niepaginowane. 


\title{
SIMPLY HUMAN CASE? \\ ARCHAEOLOGICAL REVIVAL OF THE MEMORY ABOUT THE DIFFICULT PAST, THROUGH THE TRACING OF NATURE-CULTURAL TRANSFORMATIONS OF THE WAR CEMETERIES
}

\author{
S u m m a r y
}

To reveal the process of creation, transformation, decay, destruction and re-made presence of the today forgotten final resting places of the fallen soldiers of the Great War in Central Poland (in 1914-1915) is considered as the fundamental objective for that article. We base our conclusions on the outcomes of the project "Archaeological Revival of Memory of the Great War. Material remains of the life and death in trenches of the Eastern Front and the condition of the ever changing battlescape in the region of the Rawka and Bzura" (ARM). That transdisciplinary project was conducted from 2014 to 2018, as the first in Poland material-discursive activity from the domain of prosocial archaeology of contemporary armed conflicts on such a character and scale.

We argue in the article that, the war cemeteries apart from the natural decay process, disappear almost (!) without a trace as a result of the context driven contemporary attitudes towards the material remnants of a recent difficult past - despite the fact that they are legally/ theoretically permanently protected. This applies not only to the arbitrarily selected as limited to the administrative boundaries of described here in detail Nowa Sucha commune (where poorly legible remains of the battlefields are present), but also at least to the cemeteries from three other communes (ie. Bolimów, Wiskitki and Nieborów) subjected to the archaeological revival of the memory of the Great War within the ARM project and to many other war cemeteries deprived of respect all over the world.

The article begins with sketching the emotional atmosphere that accompanied the primary context in which war cemeteries were established in the area of Rawka and Bzura in the years 1914-1915. We refer to the reflection of three witnesses to show a fully transnationally the initiating moment of the domination of war over man and landscape. Than we outline contemporaneous definitions of cemeteries and war graves and contrast them with glimpses into memories and archival documents from the war period to reveal the clashes which far-sighted consequences are observed after a hundred years. In the second part, we frame the historical context in which the resting places of the fallen soldiers of the German and Russian armies were massively created - to show in the further part of the article how the material beings of war cemeteries are entangled in the nature-cultural process of their transformation.

Making the problem of the disappearing war cemeteries from the period of the First World War the subject of ontological reflection, we try to go beyond archaeological discourse focused on epistemology by escaping form the doxa curt via prosocial activities and at the same time via referring to the concept of a new (vitalistic) materialism by showing how the vegetation growing on cemeteries became their archers and how the elements of cemetery architecture (including gravestones and relicts of the monument) contributed to the re-emergence from social chasm one of the war cemeteries (site ARM-27).

While problematising the question mark in the title (by questioning at the same time - the "simplicity" of responsibility for the material remnants of the Great War in the studied area located 
in central Poland and the purely "human" dimension of such remnants) we refer in the course of the re-interpretation of the current material condition of war cemeteries to the thesis of vibrant matter, which sensitizes us to the essence, agency, efficiency and the role of factors not fully dependent on man. Then, we show the difficulties associated with locating particular war cemeteries and signal strengths and obstacles in correlating results of archival research and use of remote sensing and archaeological methods on the way to restoring the memory of war cemeteries and establishing their current and future condition as material warnings in nowadays Central Poland. On the example of one of the cemeteries, which cognitive status has changed which caused the formal change, we show how slow and arduous, but also promising such material transformation from a forgotten / plowed cemetery into a place of (in) memory can be.

A war cemeteries as lasting in time entities as formally subjects of timeless protection, are the subjects / agents to numerous processes, mechanisms, social practices that constitute essential elements of the micro-biographies of the places, although in many cases (as in the discussed herein case of 21 war cemeteries in the territory of the Nowa Sucha commune), they were not considered to be part of them. On the example of one of the four examined within the ARM project areas of the communes (Nowa Sucha commune) we show, that war cemeteries - as such - as the elements of the nature-cultural landscape as carrying the potential of material warnings and as the triggers for reflections can be perceived as the crucial parts of the landscapes of remembrance and as the agents struggling with the continuous nature-cultural transformations.

Written by Anna I. Zalewska 